\title{
الإطار القانوني للمصنف المشترك في تشريعات دول مجلس التعاون الخّليجي
}

\section{The legal framework for the joint work in the legislation of the countries of the Gulf Cooperation Council}

\author{
إعداد الاكتتور/ أحمد رشاد أمين الهواري \\ أستاذ القانون المدني المشارك، كلية الحقوق، جامعة المملكة، مملكة البحرين \\ Email: a.amin@ku.edu.bh
}

الملخص:

لا ريب أن الإبداع الفكري ممثلاً فيما يؤلفه المؤلف من مصنفات، له أهيته التي لا تخفى على أحد، باعتباره وسيلة أساسية

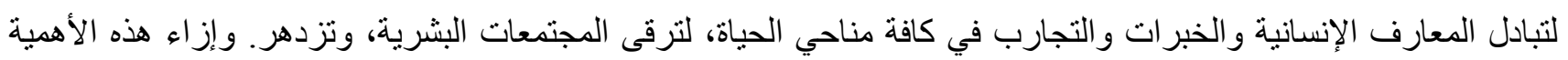
حرصت المو اثثيق الدولية، والتشريعات الوطنية على وضع إطار قانوني لحماية حقوق المؤلف على مصنفاته المبتكرة، وذلك التكان تشجيعاً للإبداع الفكري. و إذا كان وضع إطار قانوني لحماية حقوق المؤلف على مصنفاته أمر في غاية الأهمية، فإن هذه الأهمية تزداد في المصنفات التهات

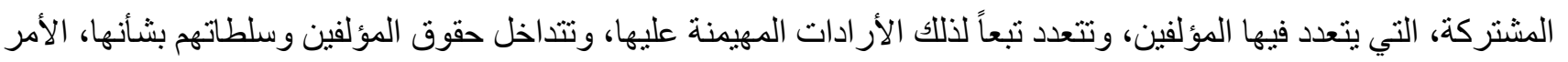
الذي قد يثير التنازع بينهم حول حقوق كلا منهم.

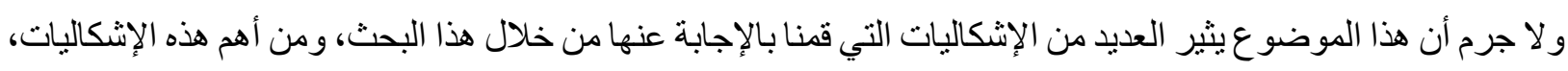

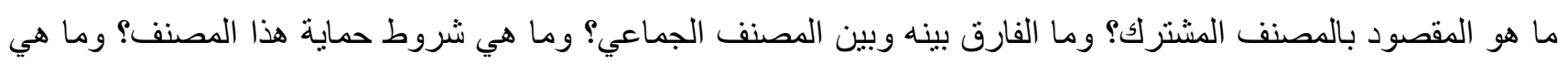

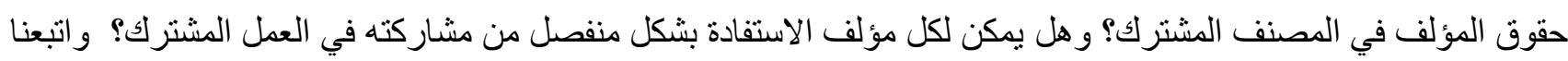
في الإجابة على هذه الإثكاليات على المنهج المقارن بين تثريعات دول مجلس النعاون الخليجي بشأن حماية حقوق المؤلف في

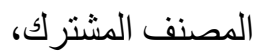
وأخيراً تنتاولنا في هذا البحث الأمور الآتية، ماهية المصنف المشترك. ثم شروط الحماية القانونية للمصنف المشترك،

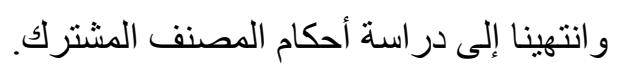
الكلمات المفتاحية: المصنف، المصنف المشترك، الابتكار ، المصنف الجماعي، الجدة 


$$
\text { المجلة الدولية لنشر البحوث والدراسات }
$$

International Journal of Research and Studies Publishing

ISSN: 2709-7064
المجلد الثاني - الإصدار التاسع عشر تأريخ الإصدار: 20 مايو 2021م

\title{
The legal framework for the joint work in the legislation of the countries of the Gulf Cooperation Council
}

\begin{abstract}
:
There is no doubt that intellectual creativity, represented by what the author composes of the works, has an indisputable importance for anyone, as it is a basic means for the exchange of human knowledge, experiences, and experiences in all aspects of life, for the advancement of human societies and prosperity. Given this importance, international conventions and national legislations have been keen to establish a legal framework to protect the rights of the author on his innovative works, to encourage intellectual creativity.

If setting up a legal framework to protect the rights of the author on his works is of the utmost importance, then this importance increases in joint works, in which there are many authors, and accordingly the wills dominating them are multiplied, and the rights of authors and their powers regarding them overlap. who are they?

It is not guilty that this topic raises many of the problems that we have answered through this research, and among the most important of these problems, what is meant by the joint work? What is the difference between it and the collective work? What are the conditions for protecting this work? What is the copyright in the joint work? Can each author separately benefit from his participation in the joint work? In answering these problems, we followed the comparative approach between the legislations of the Gulf Cooperation Council states regarding the protection of copyright in the joint work,

Finally, we dealt with in this research the following issues, what is a joint work. Then, the conditions for legal protection for the joint work, and we concluded by studying the provisions of the joint work.
\end{abstract}

Keywords: work, Joint work, Innovation, Teamwork, originality 
لا ريب أن الفكر يرتبط بالإنسان ارتباطاً كبير اً، فهو نتاج العقل، ذلك العقل الذي منّ الله سبحانه وتعالي به على الإنسان، وميزه به عن غيره من الكائنات، لييُدِع وييتكر (1)، وينمي مواهبه تحقيقا للغاية التي خلق من أجلها فهو مخلوق ابتداء ليُّتخلف في الأرض، وهو مُستخلف فيها ليحقق منهج اله في صورته الو اقعية لينشئ ويعمر (2). كما وهب الله جل و علا الإنسان - بجانب العقل ـ الإحساس والذوق ليضفي على ابتكاره، وإبداعه الجمال و الرونق، فترجم أفكاره وحولها إلى أعمالٍ أدبية وفنيةٍ لها قيمة جمالية، كالثعر والرسم و الموسيقى و النحت و غير ذلك من الأعمال. ليعبر من خلال تلاك الأعمال عن مكنونات نفسه وما يجول في خياله أو خاطره من أفكار (3). و لا ريب أن الإبداع الفكري ممثلاً فيما يؤلفه المؤلف من مصنفات (4) متنو عة سواء كانت أدبية أو فنية أو علمية، له أهميته التي لا تخفى على أحد، باعتباره وسيلة أساسية لتبادل المعارف الإنسانية و الخبر ات و التجارب في كافة مناحي الحياة،

(1 ) لذا ذاع لاى الفلاسفة الحديث عن العقل ودوره في حياة صاحبه إذ به يعز المرء أو يذل. وليس أدل على صدق ذلإنك من مقولة ديكارت

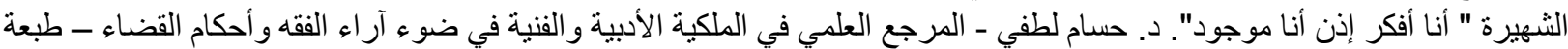

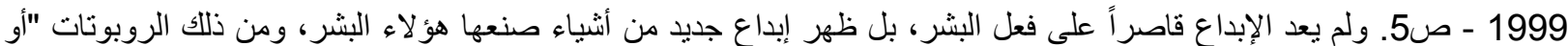

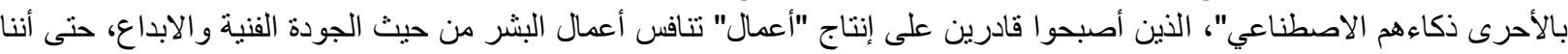

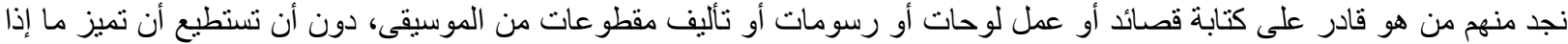

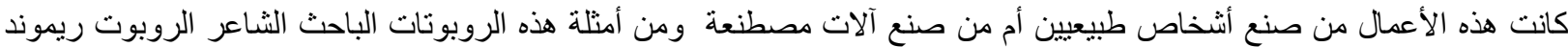

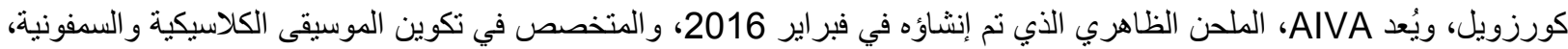

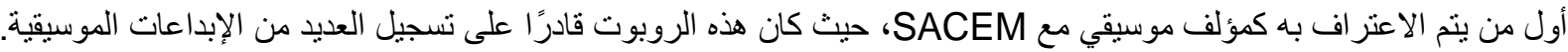

Claudia Gestin-Vilion, La protection par le droit d'auteur des creations générées par intelligence artificielle, Université Laval Québec, Canada Maître en droit (LL.M.) et Université Paris-Saclay Sceaux, France, 2017, p.2.

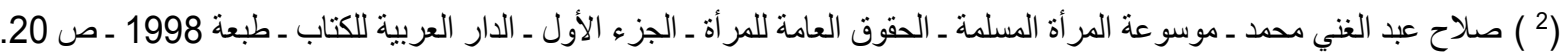

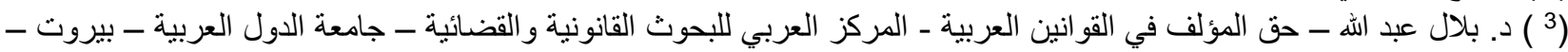

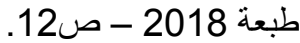

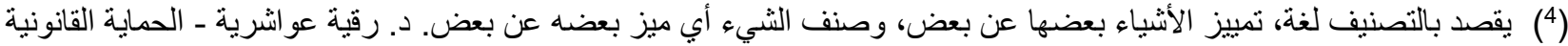

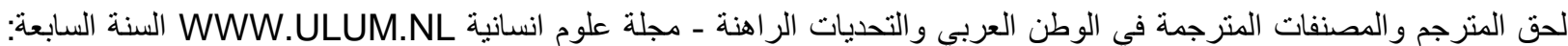

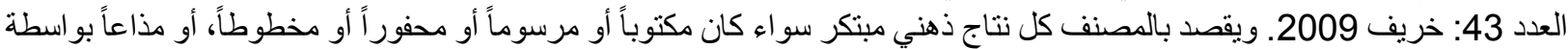

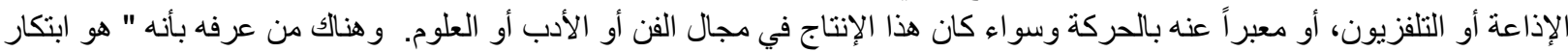

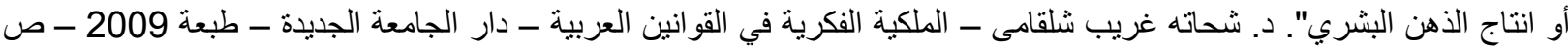

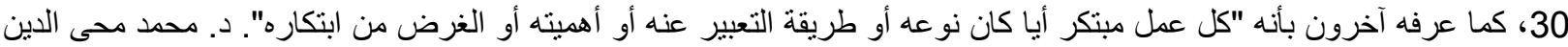

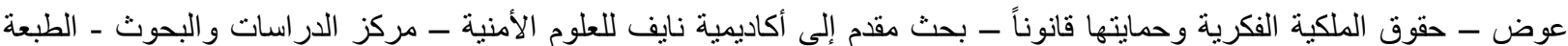

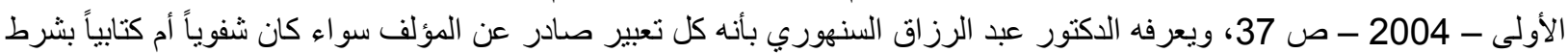

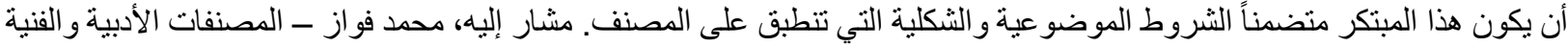

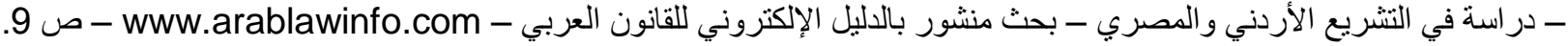
وتعرفه اتفاقية برن في المادة 2 فقرة (1) بإنه كل إنتاج في المجال الأدبي و العلمي و الفني، أياً كان شكل التعبير أو شكله.

L.T.C. Harms, A Casebook on the Enforcement of Intellectual Property Rights, $4{ }^{\text {th }}$ Edition, Switzerland, WIPO, 2018. p.62.

أما في مجال التشريع في دول مجلس التعاون الخليجي، فقد عرفه المشرع البحريني في المادة الأولى من القانون البحريني رقم 22 لسنة

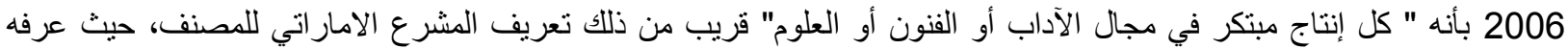

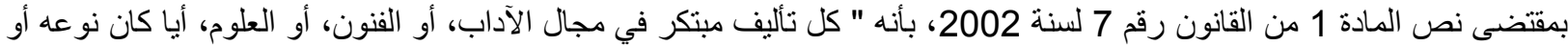


لترقى المجتمعات البشرية، وتزدهر (5). وبصفة خاصة في العصر الحالي الذي ازدادت فيه الحاجة إلى الثقافة والمعرفة إلى حد كبير، كنتيجة منطقية لتقدم التكنولوجيا، و انتشار وسائل التو اصل الاجتماعي، ومن ثُّ زيادة الوصول إلى المعرفة والترفيه.

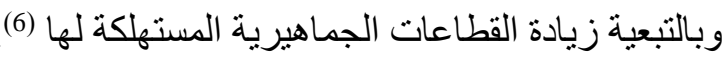
و إز اء هذه الأهمية حرصت المو اثثق الدولية (7)، و التشريعات الوطنية (8) على وضع إطار قانوني لحماية حقوق المؤلف على مصنفاته المبتكرة، وذللك تشجيعاً للإبداع الفكري. و إذا كان وضع إطار قانوني لحماية حقوق المؤلف على مصنفاته أمر في غاية الأهمية، فإن هذه الأهمية تزداد في المصنفات المشتركة، التي يتعدد فيها المؤلفين، وتتعدد تبعاً لذلك الأر ادات المهيمنة عليها، وتتداخل حقوق المؤلفين وسلطاتهم بشأنها، الأمر الذي قد يثير التنازع بينهم حول حقوق كلا منهم.

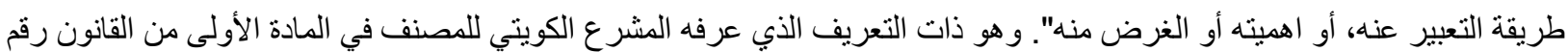

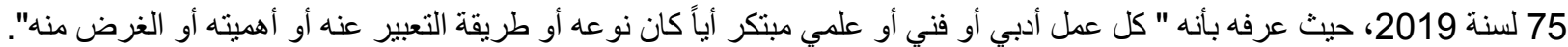

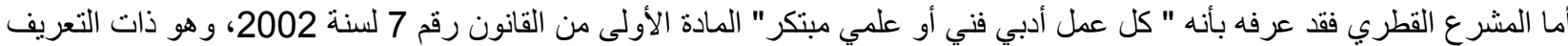

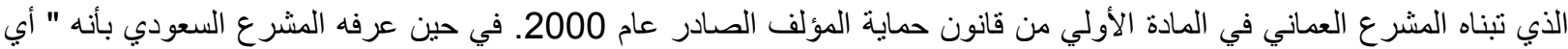

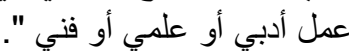
(5) د. حمدي أحمد سعد ـ الحماية القانونية للمصنفات في النشر الإلكتروني الحديث ـ دار الكتب القانونية ـ المحلة الكبرى ـ طبعة 2007 .5 - د

$\left({ }^{6}\right)$ Suhail HADDADIN, ESSAI SUR UNE THEORIE GENERALE EN DROIT D'AUTEUR, Thèse pour le doctorat en droit présentée et soutenue publiquement le 22 novembre 2008, UNIVERSITE DE POITIERS, FACULTE DE DROIT ET DES SCIENCES SOCIALES, p.2.

(60 ت أعد اتفاقية برن لحماية المصنفات الأدبية و الفنية المؤرخة 9 سبتمبر 1886، هي الصك الدولي الأول والأهم الذي يتناول حق المؤلف. L.T.C. Harms, op. cit., p.60.

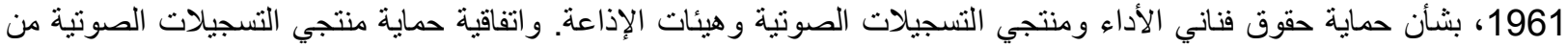

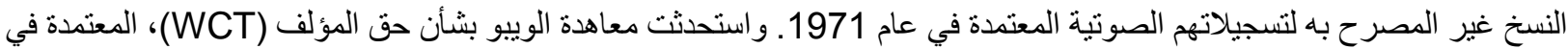

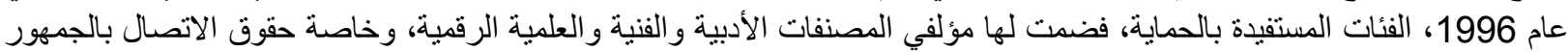

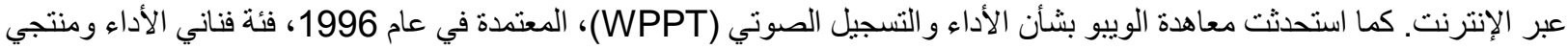

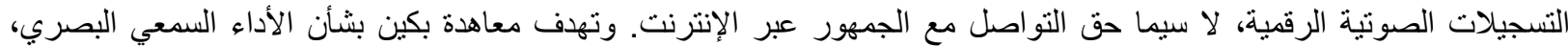

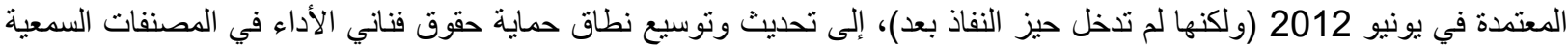

CNIPA and WIPO, Intellectual Property Basics: A Q\&A for Students China National Intellectual

Property Administration (CNIPA), Switzerland, 2019, p.18.

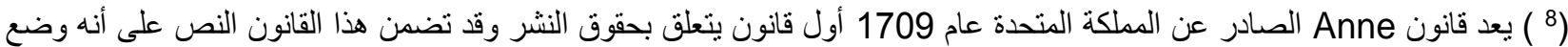

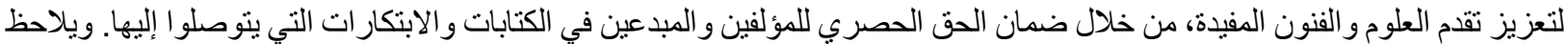

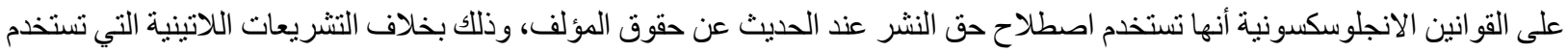

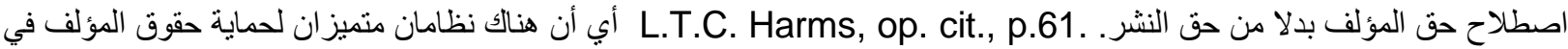

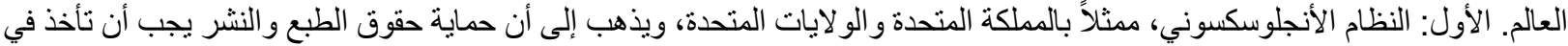

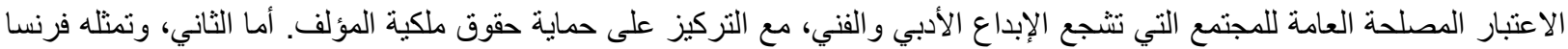

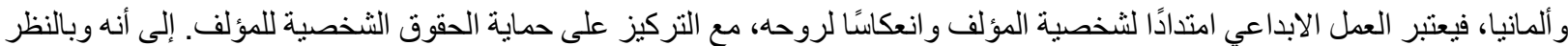

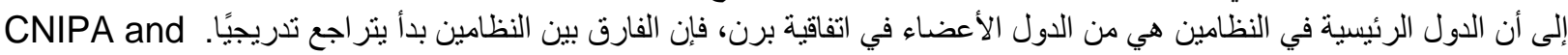

WIPO, Intellectual Property Basics, op. cit., p.38.

Suhail HADDADIN, op. cit., p.3. p.32. : انظر أيضا تطور الحماية القانونية لحقوق النشر 
الهجلة الدولية لنشر البحوث والدراسات

International Journal of Research and Studies Publishing
المجلد الثاني - الإصدار التاسع عشر تأريخ الإصدار: 20 مايو 2021م

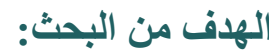

يرمي هذا البحث إلى الوقوف على مدي التماثل، والتشابه بين تشريعات دول مجلس التعاون الخليجي (محل الدراسة)، عند معالجتها القانونية للمصنفات المشتركة، والمساهمة ولو بجزء يسير في المحاو لات المبذولة في الفقه القانوني العربي لنوحيد النشريع في الدول الخليجية.

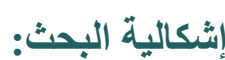

لا جرم أن هذا الموضوع يثير العديد من الإشكاليات التي سنحاول الإجابة عنها من خلال هذا البحث، ومن أهم هذه الإشكاليات، ما هو المقصود بالمصنف المشترك؟ وما الفارق بينه وبين المصنف الجماعي؟ وما هي شروط حماية هذا المصنف؟ وما هي حقوق المؤلف في المصنف المشترك؟ و هل يمكن لكل مؤلف الاستفادة بشكل منفصل من مشاركته في العمل المشترك؟ وكيف تدار عملية استغلال هذا المصنف؟

$$
\text { منهج البحث: }
$$

ستتبع الدراسة في هذا البحث المنهج المقارن بين تشريعات دول مجلس التعاون الخليجي بشأن حماية حقوق المؤلف في المصنف

$$
\text { المشترك، وهذه التشريعات هي: }
$$

1 - في مملكة البحرين: قانون رقم 22 لسنة 2006 بشأن حماية حقوق المؤلف والحقوق المجاورة المعدل بموجب القانون رقم

2 - في المملكة العربية السعودية: نظام حماية حقوق المؤلف الجديد 1424 هو لائحته التنفيذية الصادر بالمرسوم الملكي رقم م/

41 بتاريخ 2 رجب 1424.

3 - في دولة الإمار ات العربية الدتحدة: القانون الاتحادي رقم 7 لسنة 2002 في شأن حقوق المؤلف والحقوق المجاورة.

4 - في سلطنة عمان: مرسوم سلطاني رقم 65 / 2008 بإصدار قانون حماية حقوق المؤلف و الحقوق المجاورة.

5 - في دولة الكويت: قانون رقم 75 لسنة 2019 في شأن حقوق المؤلف والحقوق المجاورة.

6 - في دولة قطر: قانون رقم (7) لسنة 2002 بشأن حماية حق المؤلف و الحقوق المجاورة.

خطة البحث: هذا ولقد تتاول المشرع في دول مجلس التعاون الخليجي بالتفصيل المصنفات المشتركة مبيناً مفهومها، ومحدداً شروط حمايتهاو أحكامها. و على هدى ذلك نستعرض في هذا البحث الإطار القانوني لحماية المصنف المشترك، مخصصين لذلك بـ ثلاثة مطالب، نتناول في الأول: ماهية المصنف المشترك. ونتحدث في الثاني عن شروط الحماية القاتونية للمصنف المشترك، 


\section{المطلب الأول \\ ماهية المصنف المشترك}

بادئ ذي بدء تجدر الإشارة إلى أن مؤلف المصنف (9) قد ينفرد بإبداعه وحده دون أن يشاركه في ذلك أحد، فتؤول إليه حقوق التأليف (10) أبا كان الحق أدبياً أو مالياً، كما قد بشترك مع غبره في تأليف المصنف، فيسهر معه بموجب اتفاق وبجهد أصبل في ابتكار هذا المصنف (11)، ومن ثّم بشتركان في حقوق التأليف، ويتمتعان بذات الحماية القانونية (12).

(9 ) اهتمت التشريعات الخليجية بتحديد المقصود بالمؤلف، فعرفه المشر ع البحريني في المادة الأولى من القانون البحريني رقم 22 لسنة 2006 الإني

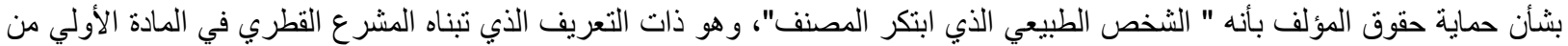

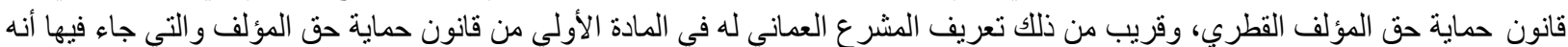

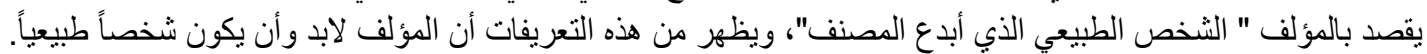

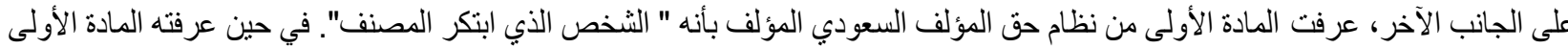

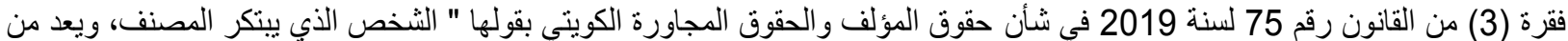

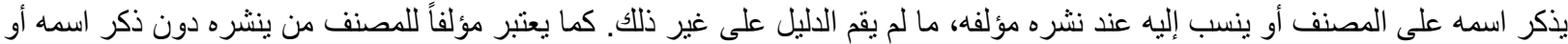

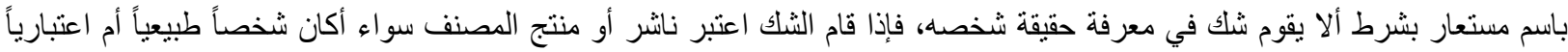

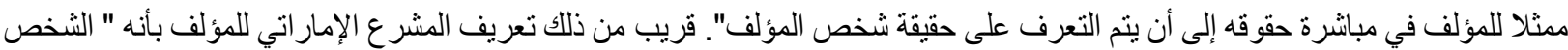

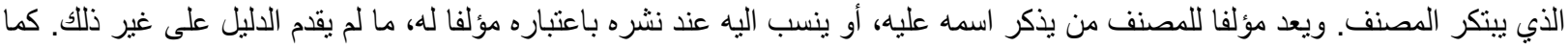

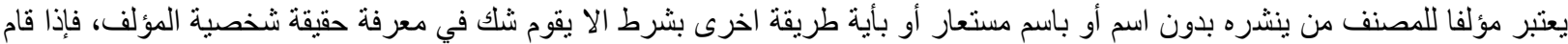

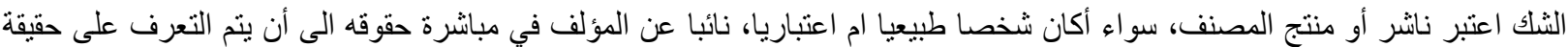

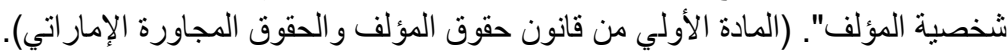

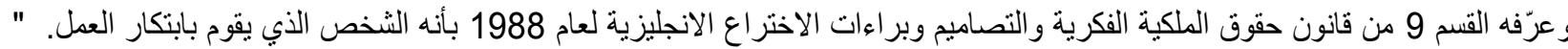
"'author' as the person who creates the work

Patrick Ager, AUTHORSHIP AND JOINT, AUTHORSHIP OF MUSICAL WORKS: A QUEST FOR COMMON STANDARDS IN EU COPYRIGHT LAW, King's College London, 2013, p.9.

(10 ) حيث تسعى التشريعات إلى تحقيق التو ازن بين حقوق المؤلف و المصلحة العامة للمجتمع في تثجيع ونشر أعمال الفنون والفكر، وفي ذلك

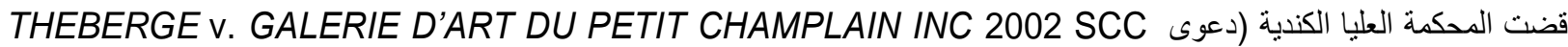

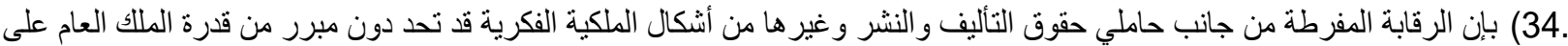

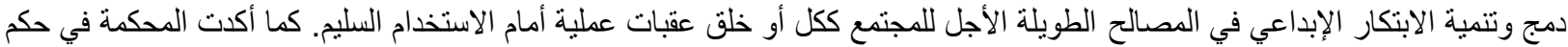

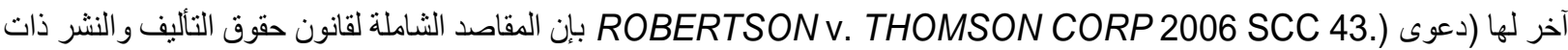

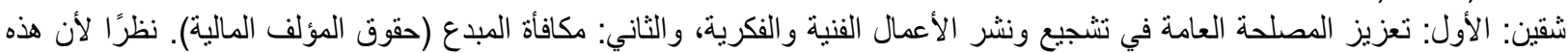

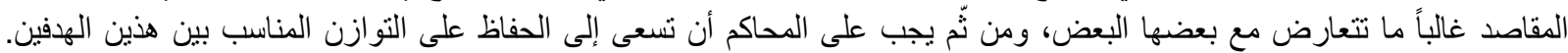
L.T.C. Harms, op. cit., p.63.p64.

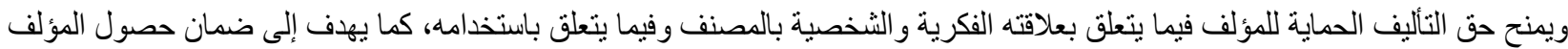
على مكافأة معقولة مقابل استخدام هذا المصنف. لويس هارمس - إنفاذ حقوق الملكية الفكرية ـ كتاب قضايا ـ الويبو ـ الطبعة الثالثة - 2012

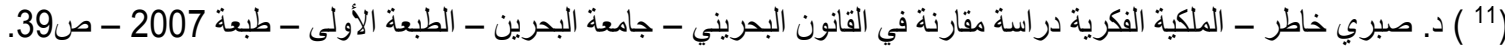

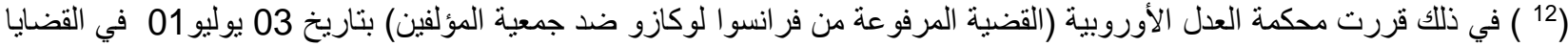
الهجمعة رقم 110/88، 241/88، 242/88 المنشور تحت رقم 2811، ECR 1989 تبأنه يحظى أصحاب حقوق المؤلف المعترف

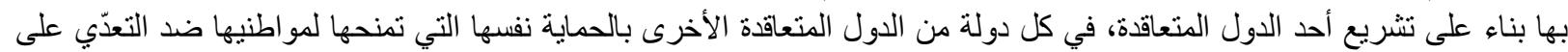

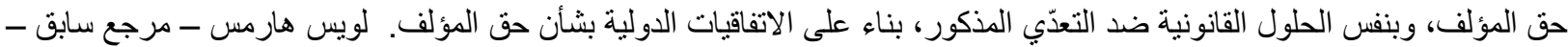


و المصنف المبتكرة من عدة أشخاص قد يأخذ أحد شكلين: الأول: يعمل فيه المؤلفين بالتزامن وبالتشاور فيما بينهم (وهو ما يطلق عليه المصنف المشترك) أما الثاني: فيكون فيه عمل المؤلفين تحت إثراف و إدارة شخص طبيعي أو معنوي (وهو ما يطلق عليه المصنفّات الجماعية). و هنا يثور التساؤل بثأن التمييز بين المصنف المشترك و المصنف الجماعي، وقبل الإجابة على هذا التساؤل بلزم تحديد المقصود بالمصنف المشترك، باعتبار أنه محور در استنا في هذا البحث. و على ذللك سنتناول في هذا المطلب در اسة مسألتين، الأولى: تحديد المقصود بالمصنف المشترك، أما الثانية، فتتمثل في التمييز

$$
\text { بين المصنف المشترك و المصنف الجماعي، وذللك على النحو التالي: - }
$$

تتعدد تعريفات المصنف المشترك وتتنوع، وهي وإن اختلفت في اللفظ فقد اتفقت في المعنى، ومع ذلك بمكن التمييز بين اتجاهيين فقهيين فيما يتعلق بتعريف المصنف المشترك، الاتجاه الأول يعرف المصنف المشترك بإنه المصنف المبتكر عن طريق تعاون اثثين أو أكثر من المؤلفين، سواء كانت مساهمة المؤلف منميزة عن مساهمة المؤلفين الآخرين أم لم تكن كذللك (13). أما الاتجاه الثاني، فهو يعرف المصنف المشترك بأنه "المصنف الذي ييتكره مؤلفان أو أكثر بالتعاون المباشر سويا، وبعد الأخذ في الحسبان المساهمات المتبادلة لكل و احد منهم، و التي يصعب الفصل بينهما و النظر إليها باعتبار ها ابتكار ات مستقلة" (14). ذات الأمر نجده في نشريعات دول مجلس التعاون الخليجي (15)، حيث انقست التشريعات إلى مذهبين، الأول منهما: وهو الغالب في التشريعات الخليجية، يعرف المصنف المشترك بانه ذلك المصنف الذي ساهم في ابتكاره أكثر من مؤلف، سواء أمكن

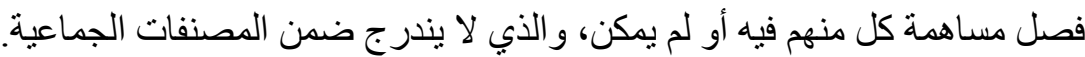
و هذا التعريف هو الذي تبناه المشر ع البحريني في المادة الأولي من قانون حماية حقوق المؤلف، حيث عرف المصنف المشترك بانه "المصنف الذي ساهم في ابتكاره أكثر من مؤلف، سواء أمكن فصل مساهمة كل منهم فيه أو لم يمكن،

$\left({ }^{13}\right)$ Caroline G. Ouellet, Oeuvre créée ou non créée en collaboration? Là est la question, LEGER ROBIC RICHARD/ROBIC, 2004, p.877.

-Deborah E. Bouchoux -ntellectual Property - The Law of Trademarks, Copyrights, Patents rand

Trade Secrets - Fourth Edition-Printed in the United States of America - p.229.

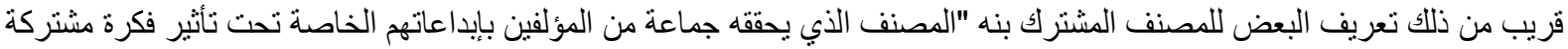

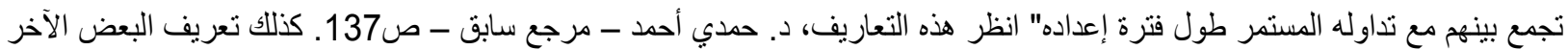

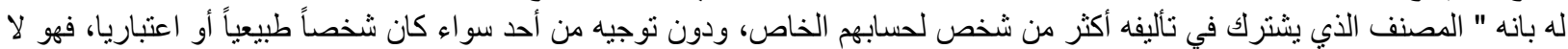

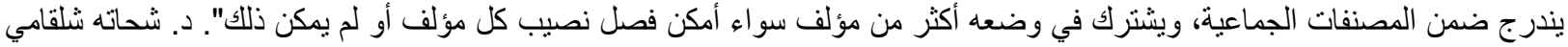

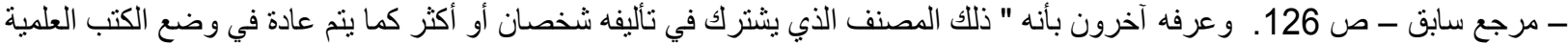

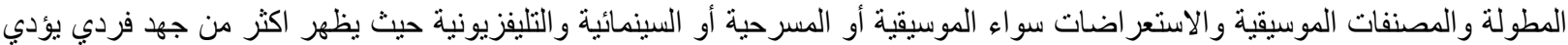

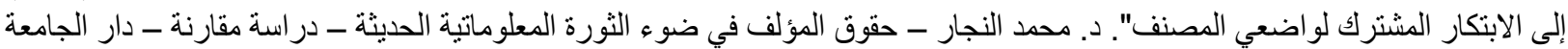

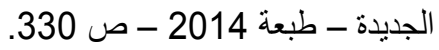

(14) قريب من ذلك تعريف المصنف المشترك بانه " المصنف الذي ينعاون في إبداعه شخصان أو أكثر بطريقة يمتزج من خلاله إسهام كل منهم

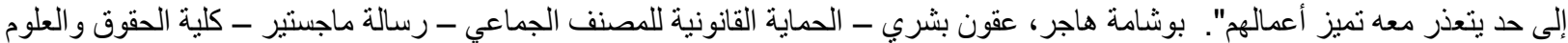

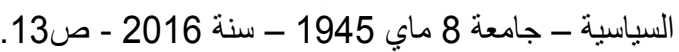

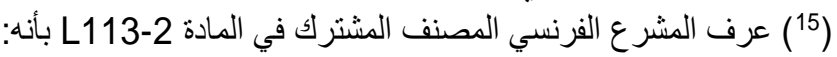

"Est dite de collaboration l'oeuvre à la création de laquelle ont concouru plusieurs personnes physiques." 
المجلة الدولية لنشر البحوث والدراسات

International Journal of Research and Studies Publishing
المجلد الثاني - الإصدار التاسع عشر تأريخ الإصدار: 20 مايو 2021م

و الذي لا يندرج ضمن المصنفات الجماعية". وهو ذات التعريف تقريباً الذي تبناه المشرع الامار اتي، في المادة الأولي من قانون حقوق المؤلف (16.) و المشرع العماني في الفقرة (7) من المادة الأولى من قانون حقوق المؤلف(17) ، قريب من ذلك تعريف المشرع الكويتي - في الفقرة (5) من المادة الأولى ـ لهذا المصنف بأنه " مصنف لا يندرج ضمن المصنفات الجماعية ويشارك في تأليفه أكثر من مؤلف، سو اء أمكن فصـل مساهمة كل منهم في أو لم بمكن". أما المقنن السعودي فقد عرف المصنف المشترك بأنه " المصنف الذي يشترك في وضعه شخصان أو أكثر من الأشخاص لهر الطبيعيين أو المعنويين سو اء أمكن فصل إسهام كل منهم في العمل أم لم يمكن ذلك". وذهب الفريق الثاني من التشريعات إلى أن المصنف المشترك هو ذلك " المصنف الذي يساهم في إخر اجه مؤلفان اثنان أو أكثر ويمكن فصل عمل كل منهم وتمييزه على حده". (التشريع القطري، المادة الأولي من قانون حماية حقوق المؤلف والحقوق المجاورة).

\section{ويظهر لنا من التعريفات السابقة الآتي:}

1 - إن التشريعات الخليجية ـ فيما عدا التشريع القطري - يؤيدها في ذلك بعض الفقه، قد أخذت بالمعنى الموسع لفكرة الاشتراك(18)، ومن ثّم اعترفت بنو عين من الاشتراك والتعاون في ابتكار المصنف، النوع الأول: الاشتراك المطلق، ويتمثل الاشتر الك، في هذا النوع من المصنفات، في ذوبان شخصية جميع المؤلفين في المصنف على نحو لا يمكن الفصل فيه بين إساهم و إبداع كل منهم، ومن أمثلة ذلك اشتر اك أكثر من نحات في نحت تمثال، وتأليف قصنة موسيقية من أكثر من فنان (19)، ففي هذا المصنف لا يمكن فصل عمل كل واحد من المشاركين فيه. أما النوع الثاني: (الاشتراك النسبي) فيتمثل في اشتر الك أكثر من مؤلف في تأليف المصنف على نحو لا يندمج مساهمة كل منهم بمساهمة الآخر ويمكن تمييزه وفصله، ومن أمثلة ذلك المصنفات

السمعية البصرية، التي يشنرك في إعدادها أكثر من مؤلف (المخرج، مؤلف القصة، مؤلف السيناريو، مؤلف الموسيقى ...). على الجانب الآخر نجد أن المشرع القطري يناصره البعض الآخر في الفقه، قد قصر المصنفات المشترك على النوع الثاني فقط (الاشتر اك النسبي)، حيث اعتبر المصنف مشتركاً إذا ساهم في إخر اجه مؤلفان اثنان أو أكثر،

(16) حيث نصت المادة الأولي من التشريع الإماراتي على أن " المصنف الذي يساهم في وضعه عدة اشخاص سواء أمكن فصل نصيب كل منهم

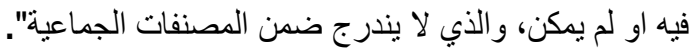

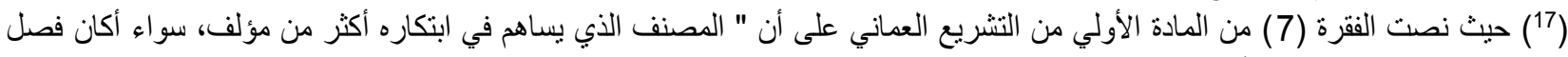

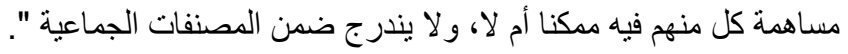

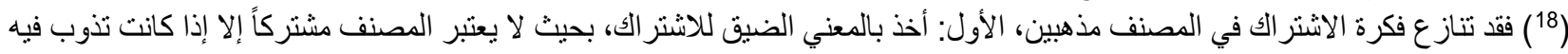

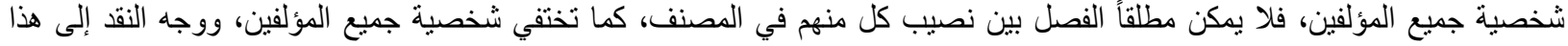

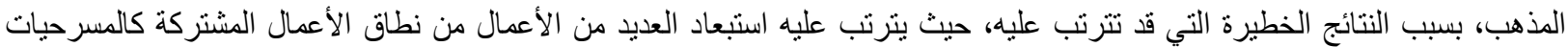

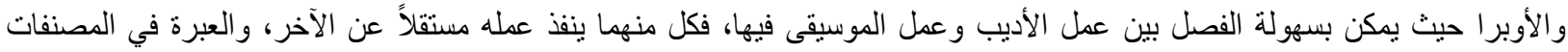

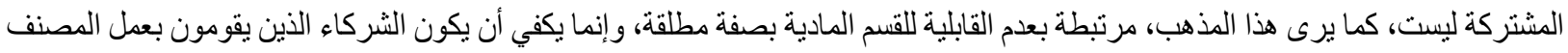

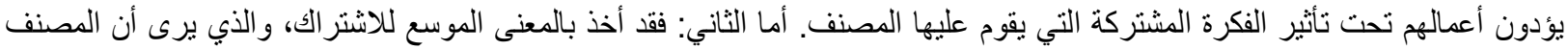

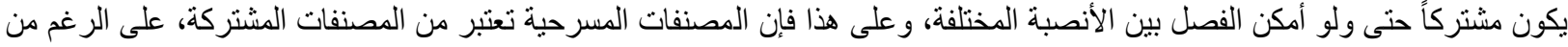

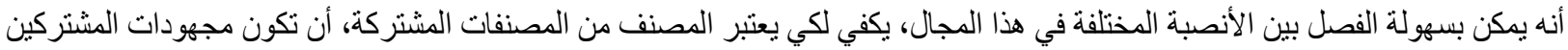

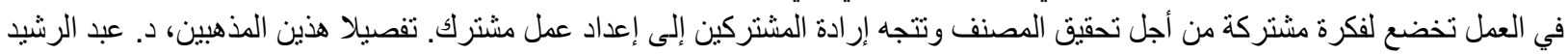

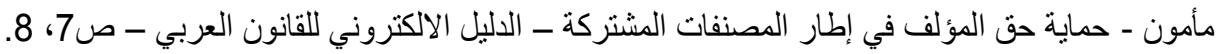

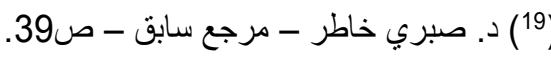


مع إمكان فصل عمل كل منهم عن الآخر وتمييزه على حده، فإذا اندمجت مساهمة المؤلفين على نحو لا يمكن فصل عمل كل منهم عن الآخر لا يعتبر هذا المصنف من قبيل المصنفات المشتركة، وهو قول محل نظر لتعارضه مع نصوص التشريع القطري ذاته الذي ميز المصنف المشترك المطلق عن المصنف المشترك النسبي في الأحكام التي يخضع لها كل منهما. هذا من ناحية، ومن ناحية أخرى هناك مصنفات لا خلاف على كونها مصنفات مشتركة ومع ذلك لا يمكن فصل عمل كل مؤلف عن الآخر ، كحالة اشتر اك أكثر من فنان في نحت تمثال أو رسم لوحة، وعلى ذلك يمكن القول إن المصنفّ المشترك، قد يكون من الممكن فصل مساهمة أي من المؤلفين وقد لا يمكن ذلك (20). 2 - إن المشرع في دول مجلس التعاون الخليجي قد حرص على التأكيد على أن المصنفات المشتركة لا تدخل ضمن المصنفات الجماعية، وأر اد بذلك استبعاد فكرة الثخص الموجه الذي يقوم بالتنسيق بين المؤلفين عند وضع المصنف (21). 3 - إن المقن السعودي ـ على خلاف باقي المشر عين الخليجيين - قد اعتبر المصنف مشتركاً سواء كان قد تم بالتعاون بين أثخاص طبيعيين أو بين أثخاص اعتباريين، ونرى أن هذا المنهج محل نظر، حيث أن الابتكار ، كعنصر مميز للمصنف،

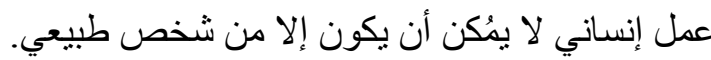
ومن أمثلة المصنفات المشتركة بنو عيها، تأليف كتاب مشترك بين عدة مؤلفين في القصة القصبرة أو الثعر أو النثر أو الخر ائط المعمارية أو إعداد بحث علمي أو بحث قانوني أكاديمي لأغر اض الدر اسة الجامعية. ومن هذه الأنواع أيضا المصنفات

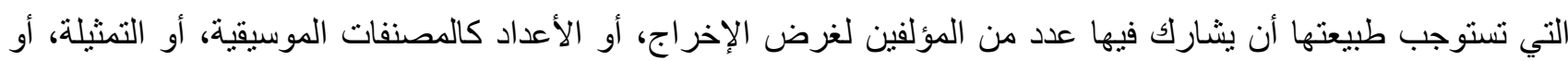

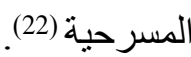

وفي جميع الأحو ال لا يعد شريكاً في المصنف من يسدي نصيحة أو يطرح فكرة مجردة لا نظهر في تعبير إبداعي أو يقوم بتعديل المصنف بإضافة لاحقة دون اتفاق، فالأول لم يعبر عن فكرته، فلم تخرج إلى حيز الوجود المحسوس، وهو ما يتناقض مع فكرة الاشتر الك، التي تقتضي أن يبذل كل مؤلف جها حقيقيا في إعداد المصنف بشكله النهائي، و لا يعني ذلك ضرورة أن يساهم كل مؤلف شريك في كل جزئية من العمل المشترك (23). و الثاني يعتبر مؤلفاً لمصنف مشتق، حيث أن المصنف المشترك يلزم فيه وجود نية الاشتر اك لدى المؤلفين(24)، وهو غير متحقق في المصنف المشتق.

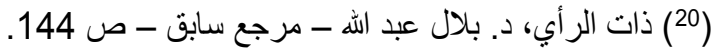

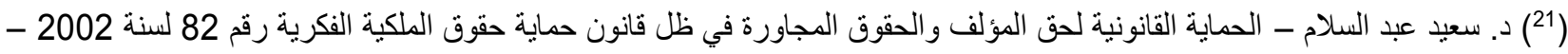
دار النهضة العربية - طبعة 2004- ص صنداند 59.

(22) -Deborah E. Bouchoux -ntellectual Property - op.cit - p.229.

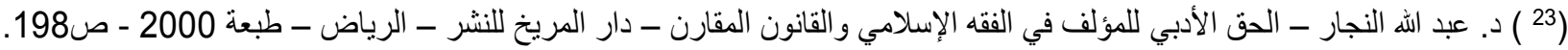

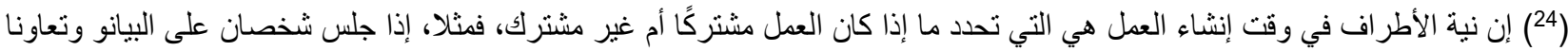

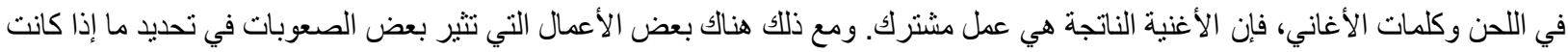

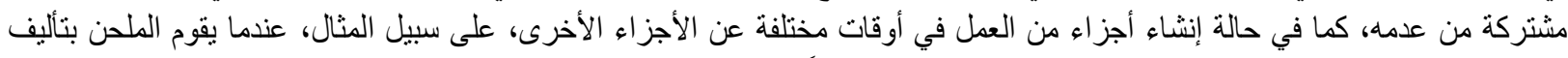

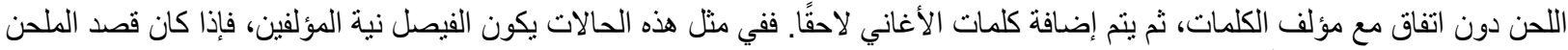

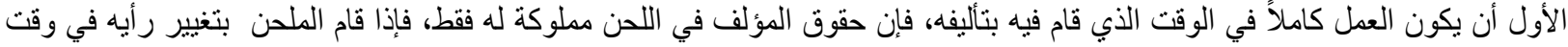

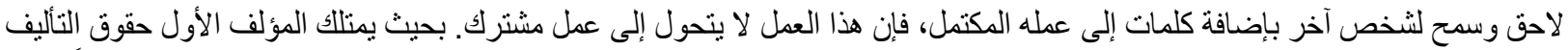

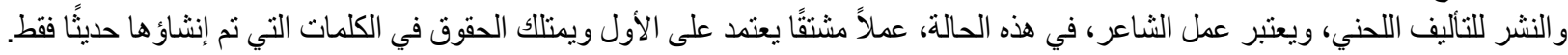
ما لم يعتزم الطرفان في الوقت الذي يقدمان فيه مساهماتهما أن يتم دمج الأجزاء أو استيعابها في وحدة متكاملة. Deborah E. Bouchoux-ntellectual Property - op.cit - p.230. 
ثناتياً: التمييز بين المصنف المشترك والمصنف الجماعي:

يتشابه إلى حد كبير المصنف المشترك مع المصنف الجماعي، حيث يلزم في كلاهما اثتر اك أكثر من شخص ومساهته في ابتكار مصنف معين، إلا أنها يختلفان في الخصائص التي تميز كلا منهما، وكيفية إدارتهما، فضلا عن تحديد من يكتسب صفة المؤلف في هذه المصنفات، وحيث أن التعرض للانقاط السابقة بالتفصيل لا محل له في هذا البحث، فهو يحتاج إلى دراسة مستقلة، فسنكتفي هنا بالتعرف على مفهوم المصنف الجماعي وأهم ما يميزه عن المصنف المشترك. وفي هذا الإطار يمكن القول أنه يقصد بالمصنف الجماعي ذلك المصنف الذي تم ابتكاره بمبادرة من شخص طبيعي أو اعتباري يتكفل بإصداره ونشره والكثف عنه تحت إثر افه وباسمه، وفيه تندمج مشاركات كافة المؤلفين المشاركين في تحقيق الهدف العام الذي حدده هذا الثخص، دون أن يكون من الممكن أن ننسب لكل منهم حقًا متميزًا على كامل ما تم تحقيقه(25. وهذا التعريف تبنته التشريعات

$$
\text { الخليجية مع اختلاف الصياغة(26). }
$$

ويستفاد من ذلك أن المصنف الجماعي يفتر ضيّ فيه أن يشترك جماعة من الأشخاص الطبيعيين في وضعه، فيدلى كل منهم بدلوه في هذا العمل، فيندمج عمل المشتركين في إعداده، ويكون نصيب كل منهم مجهو لا، بحيث يكون من المتعذر معه تجزئته(27)، وفصل عمل كل فرد من المساهمين فيه عن عمل الآخر ، ويكون هذا الاشتر الك بتوجيه من شخص طبيعي أو معنوي تحقيقاً لهدف معين(28)، على أن يتكفل هذا الأخير بنشره، تحت إدارته وإثر افه، على أن ينسب هذا العمل له، بحيث يعتبر هذا الثخص مالكا للمصنف الجماعي، وذلك على الرغم من كون دوره يقتصر على توجيه هذا الابتكار و إدارته (29).

$\left({ }^{25}\right)$ Distinction œuvre de collaboration/ œuvre collective -

recherche.unicaen.fr/.../com.univ.collaboratif.utils.LectureFichierg.

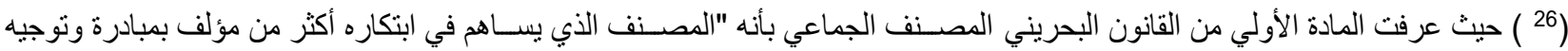

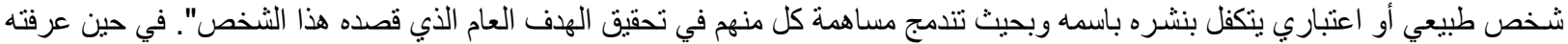

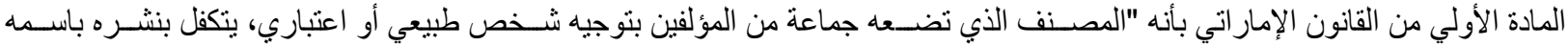

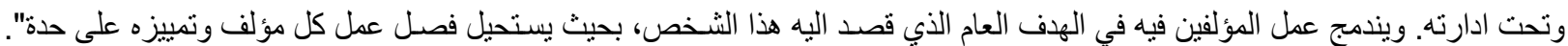

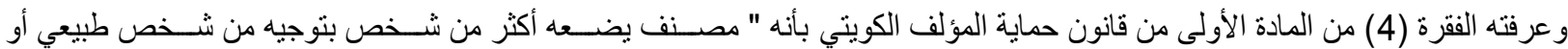

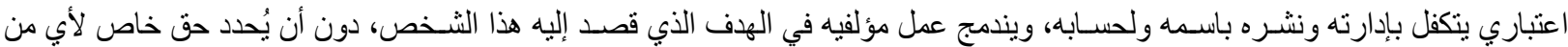

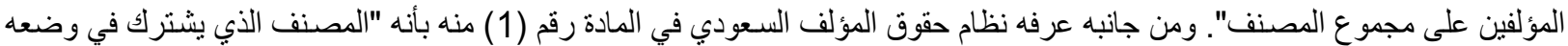

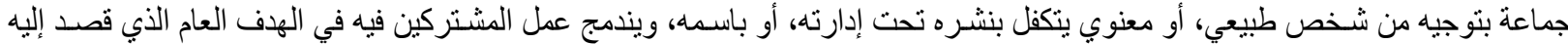

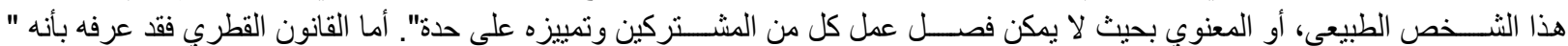

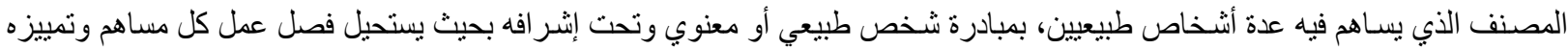

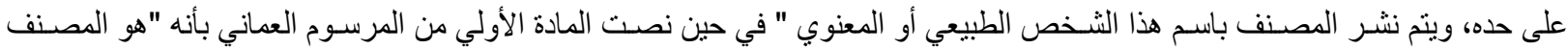

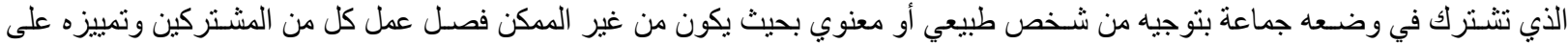

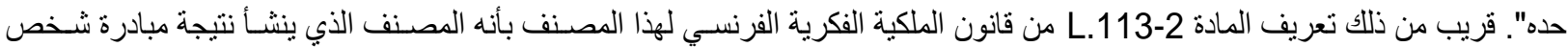

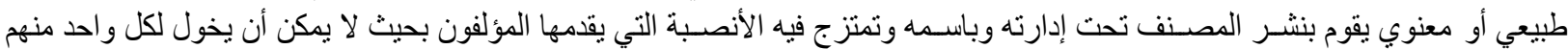

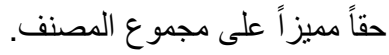

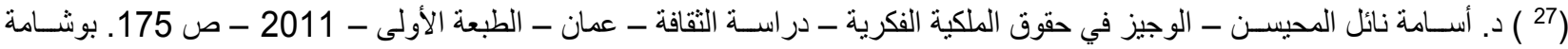

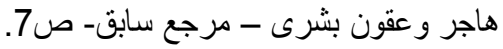

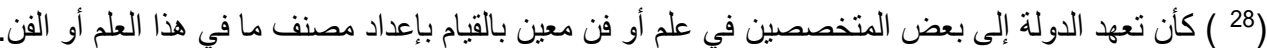

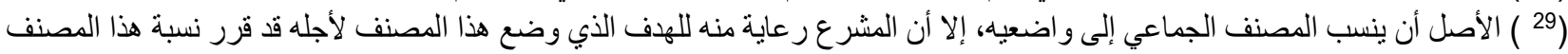

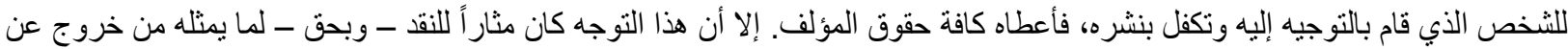
الو اقع، ومخالفة الأوضاع القانونبة السليمة، فقد كان ينبغي الاعتراف لمؤلفي هذا المصنف بحقوق المؤلفين، بحيث يكون لهم على المصنف 
و عليه يشترط لاعنبار المصنف مصنفاً جماعياً الثروط الآتية: 1 - وجود جماعة من المؤلفين: ويعني ذلك أنه يشترط أن يضع المصنف جماعة من المؤلفين، ولم يحدد المشرع في التشريعات محل المقارنة ـ عدا التشريع البحريني ـ حد أقصى أو حد أدني، حيث تضمن النصوص لفظ " جماعة " أو "عدة أثخاص"، الأمر الذي يستفاد منه ألا يقل العدد عن ثلاثة أثخاص (أي أكثر من شخصين) حتى نكون أمام جماعة (30). على خلاف ذلك نجد المشرع البحريني قد اكتفى لتحقق الجماعة أن يشترك في وضع المصنف الجماعي أكثر من شخص، أي أنه بعتبر المصنف جماعي إذا قام به مؤلفان أو أكثر ، هذا و لابد أن تتكون الجماعة من أشخاص طبيعيين لأن الثخص المعنوي لا يمكن أن يبتكر مصنفاً (31). 2 - وجود شخص موجه: لقد اشترط المشرع - في الدول محل الدراسة ـ أن تضع الجماعة المصنف بتوجيه من شخص، يستوي بعد ذلك أن يكون هذا الشخص طبيعياً أو معنوياً، كل ما هنالك أنه يقوم بالإشر اف على عمل المؤلفين (32)، ويتعهد بنشر المصنف باسمه. فذور المو جه هنا يتمثل في التنسيق و التنظيم بين المؤلفين، فيقوم بتجميعهم، ووضع خطة العمل اللازمة لإنجاز المصنف، ومتابعة عملهم، ثم نشر المصنف، كل ذلك دون أن يكون له دخل في عملية الابتكار و التأليف (33). 3 ـ اندماج عمل كل مؤلف مع عمل الآخر: فيشترط أن بندمج عمل كل مشارك في المصنف مع عمل الآخر، بحيث لا يمكن تحديد عمله في المصنف وتمييزه على حده (34)، و هذا الثرط من الثروط الو اجب تو افرها في أي عمل مشترك، فالجماعة شركاء في المصنف، وتسري عليهم أحكام الاشتر الك لولا وجود الثخص الموجه. ومن استعر اض هذه الثروط يتضح لنا أن أهم ما يميز العمل الجماعي عن العمل المشترك، هو وجود الثخص الموجه من عدمه، فالمصنف الجماعي يكون من وضع جماعة من المؤلفين، وبتوجيه من شخص طبيعي أو اعتباري (الثخص الموجه) يتكفل بنشره باسمه وتحت إدارته. و أن عمل المشتركين فيه يندرج في الهدف العام الذي قصده هذا الموجه،

السلطات الأدبية والمادية، وبحيث تظل لهم صفة المؤلف حتى ولو تنازلوا عن سلطاتهم المادية. د. شكري سرور ـ النظرية العامة للحق ـ دار

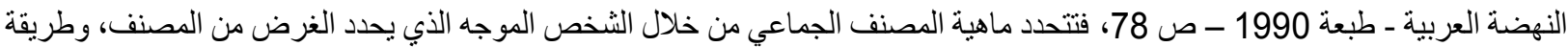

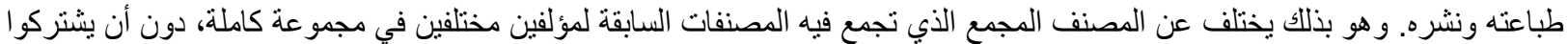

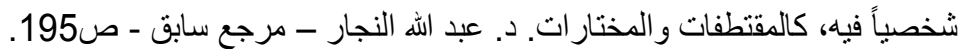

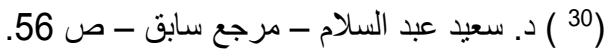

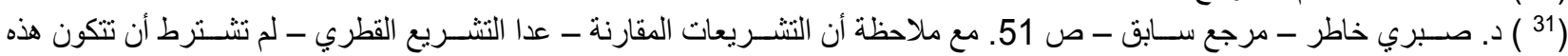

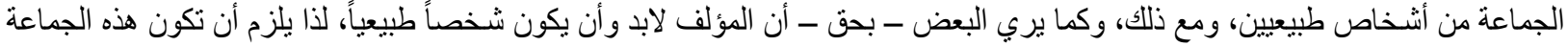
من الأثخاص الطبيعيين. (32 ) وقد يرتبط الثــخص الموجه بالمؤلفين بعلاقة عمل، كما لو كانوا موظفين لديه، كما قد يربط بينهم عقد مقاولة إذا كان هؤ لاء المؤلفين يعملون

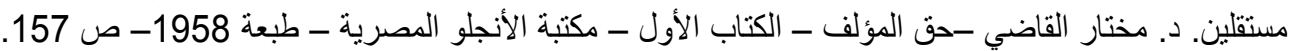

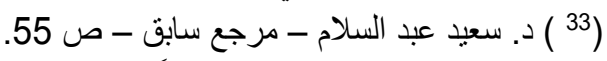

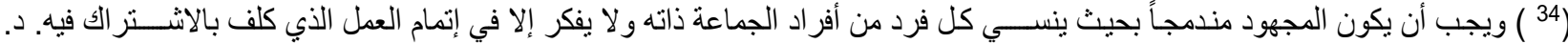

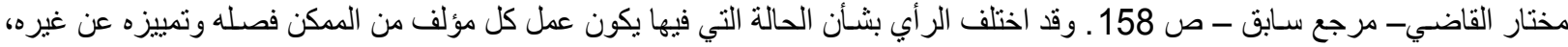

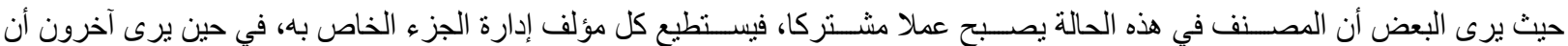

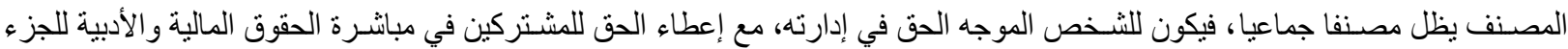

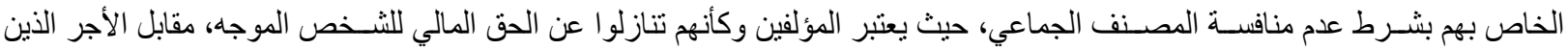


المجلة الدولية لنشر البحوث والدراسات

International Journal of Research and Studies Publishing
المجلد الثاني - الإصدار التاسع عشر تأريخ الإصدار: 20 مايو 2021م

ISSN: 2709-7064

و أنه لا يمكن فصل عمل كل المشتركين وتمييزه على حده، لذا فقد قرر المشرع أن يكون للشخص الموجه بابتكار "وضع وتأليف" المصنف الحق في أن يباشر وحده حقوق المؤلف الأدبية و المالية عليه ما لم يقض الاتفاق خلاف ذلك (35).

\section{المطلب الثاني \\ الشروط الواجب توافرها في المصنف المشترك لحمايته}

لقد حرص المشرع في القانون المقارن عند إسباغ الحماية القانونية على المصنفات الأدبية و الفنية والعلمية أن بحدد هذه المصنفات، معددً إياها - على سبيل المثال لا الحصر - مع أخذه في الاعتبار تحديد الثروط اللازمة لحماية هذه المصنفات، والتي يمكن من خلالها التمييز بين المصنفات المحية وغير المحمية، وتظهر هذه الثروط من التعريف الذي تبنته معظم التشريعات الخليجية للمصنف المحمي، حيث عرفت المصنف بأنه كل إنتاج مبتكر في مجال الآداب أو الفنون أو العلوم.

ويظهر لنا من هذا التعريف أن المصنف لا يكون جدير اً بالحماية إلا إذا تو افر فيه شرط الابتكار، إلا أن حماية المصنف

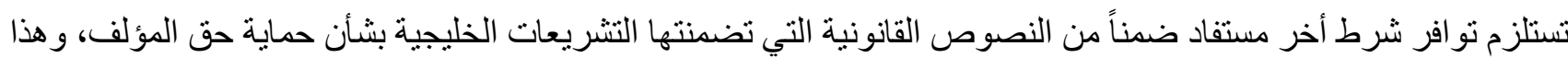
الثرط هو التعبير عن المصنف.

و عليه يمكن القول إنه يشترط لحماية المصنف شرطان، الابتكار و التعبير عن المصنف، وسنتعرض لهذين الشرطين فيما يلي بالتفصيل مخصصين لكل منها فر عاً مستقلاً وذلك على النحو التالي: -

$$
\text { الفرع الأول: شرط الابتكار (الضابط الثخصي). }
$$

الفرع الثاني: شرط التعبير عن المصنف (الضابط الموضوعي).

(35 ) و هو ما أكتته محكمة التمييز الإمار اتية في حكم لها بقو لها "ما كان النص في المادة (1) من القانون الاتحادي رقم (7) لسنة 2002 في شـأن

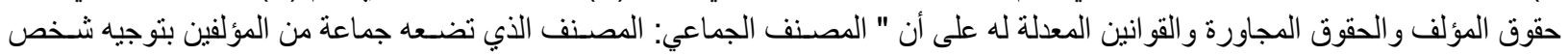

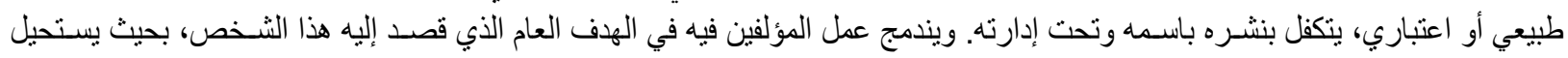

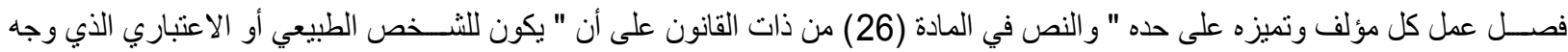

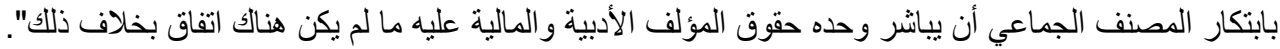

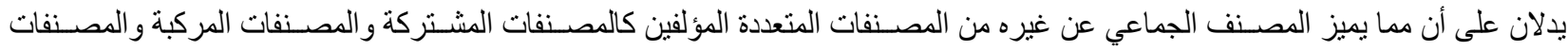

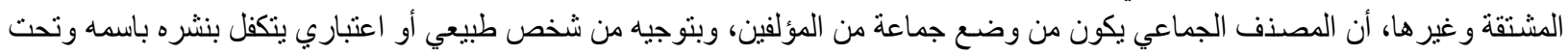

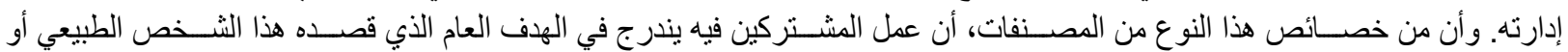

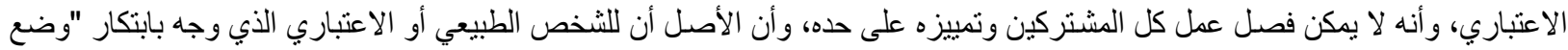

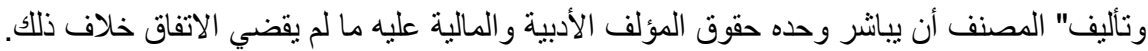

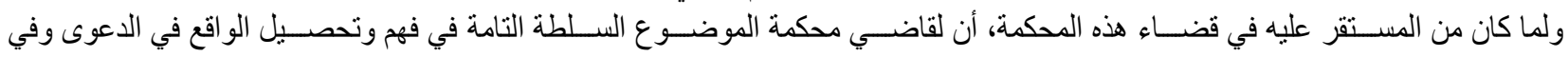

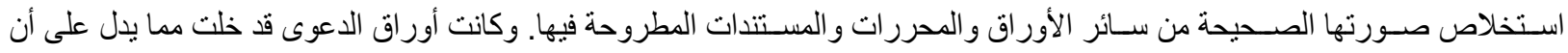

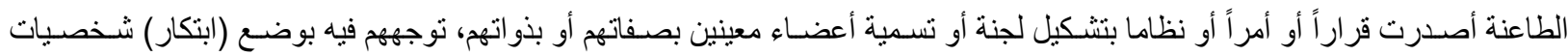

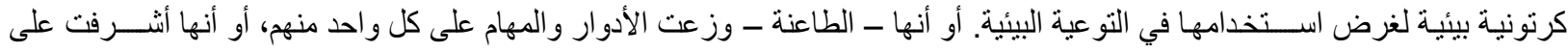

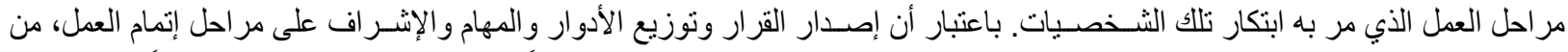

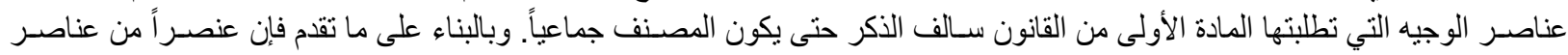

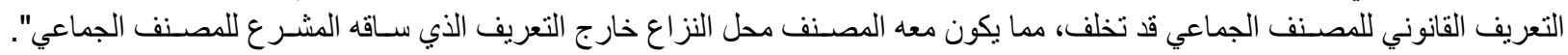
الطعن رقم 51 لسنة 2013 قضائية بتاريخ 2013-06-05. 


\section{الفرع الأول}

\section{الابتكار}

يكاد يجمع الفقه على ضرورة تو افر شرط الابتكار كعنصر مميز للمصنف المحمي قانوناً عن غيره من المصنفات

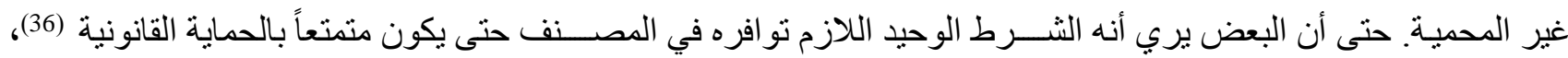
ويعني ذلك أنه يثترط لإسباغ الحماية القانونية على المصنف أن يكون مبتكر أ، والابتكار هو البصمة الثخصية للمؤلف، بحيث تستكثف شخصية المؤلف من مقومات الفكرة التي عرضها أو من الطريقة التي سلكها لعرض هذه الفكرة (37).

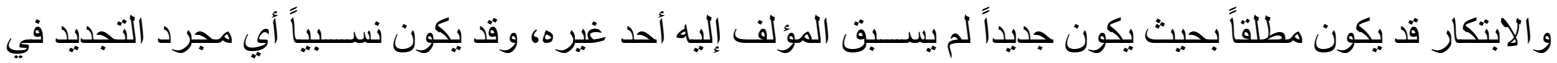
طريقة العرض و التأصيل أو الاسلوب. ففي الحالتين يعد المصنف مبتكراً إذا كان مطبو عا بشخصية المؤلف وطابعه الميز. وسنتاول فيما يلي شرط الابتكار بثيء من التفصيل سواء من حيث ماهيته أو صوره مخصصين لذلك الغصنين

\section{الغصن الأول: ماهية الابتكار. \\ الغصن الثاني: صور الابتكار.}

\section{الغصن الأول \\ مفهوم الابتكار}

من المسلم به أن المصنف لا يكون جدير بالحماية إلا إذا كان أصلياً أو ينسم بالإبداع، وهو لا يكون أصليًا إلا إذا كان

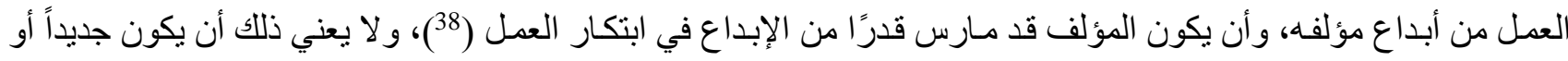

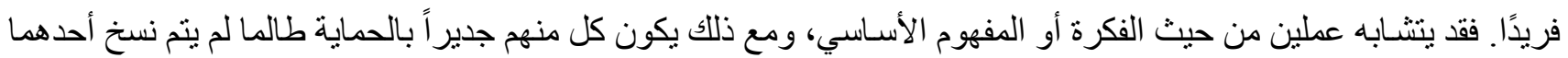
من الآخر (39).

Chapitre préliminaire Présentation de la propriété littéraire et artistique - p. 13. https://www.editionsellipses.fr/PDF/9782340015739_extrait.pdf.

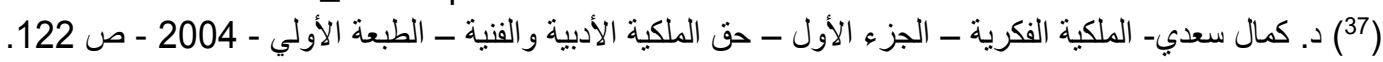

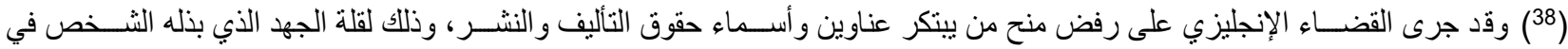

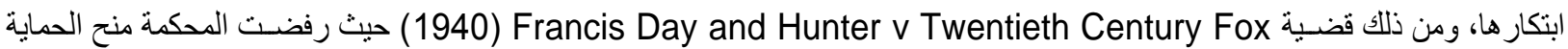

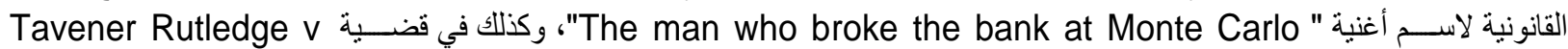
Trexpalm

Catherine Colston, LLB, LLM- Principles of Intellectual Property Law- Cavendish Publishing Limited First published in Great Britain 1999 -P168.

$\left.{ }^{39}\right)$ Deborah E. Bouchoux -ntellectual Property - op-cit - p.193.

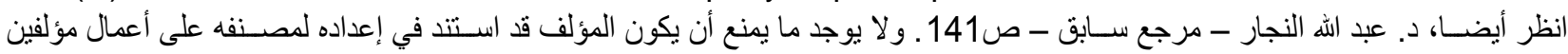

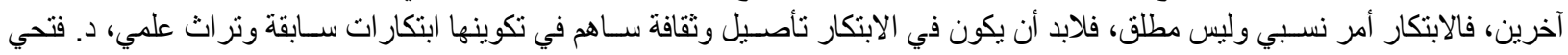

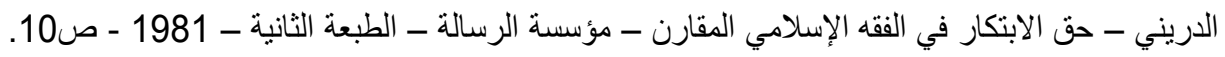


ويقصـــ بالابتكار ـ كما عرفه المثـرع ع الإمار اتية و العماني ـ الطابع الإبداعي الذي يسـبغ على المصـنف الأصـالة

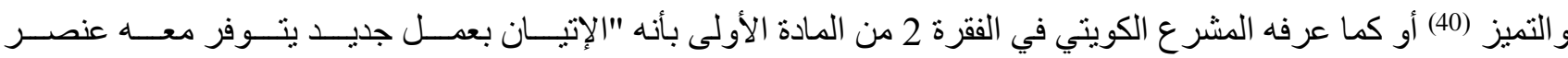
الأصــالة، أو تجديد عمل موجود أو تطويره بحيث يتميز هذا التجديد أو التطوير بطابع خاص". أو هو - كما عرفه المشرع السعودي _ “الإنشاء الذي توفرت فيه عناصر الجدة أو تميز بطابع خاص غير معروف من قبل". و إذا كانت التشريعات الثنلاث الششار إليها قد حرصت على تحديد المقصود بالابنكار، فعلى الجانب الآخر نجد أن باقي التشريعات المقارنة قد جاءت خلو ا من ثمة تعريف له.

ويستفاد مما سبق أن التشريعات الخليجية عند تحديدها لمفهوم الابتكار قد انقسمت إلى ثلاثة مذاهب، المذهب الأول: ويتبناه المقنن السعودي والمشرع الكويتي (41) ويأخذ بالجدة أو الحداثة كمعيار مميز للمصنفات الجديرة بالحماية،

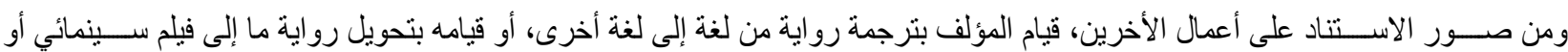

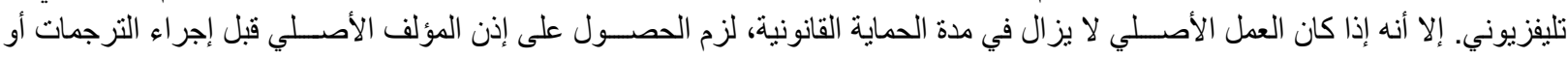

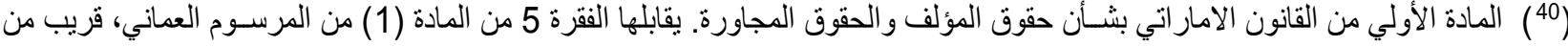

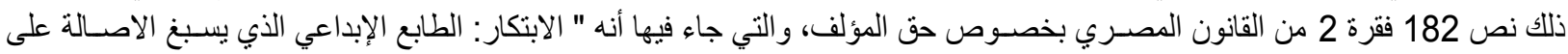

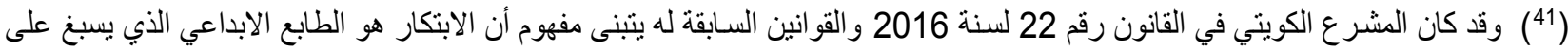

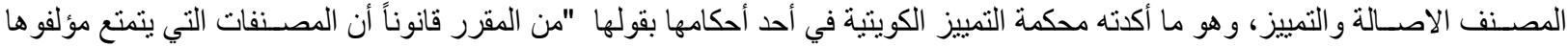

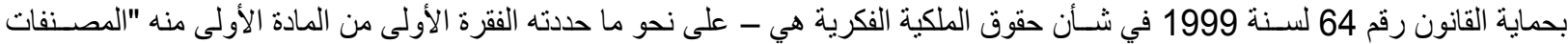

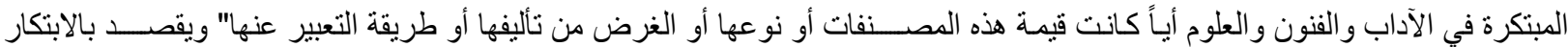

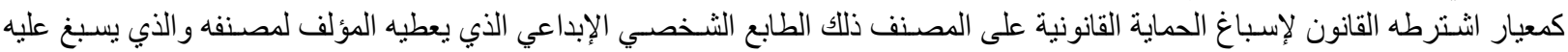

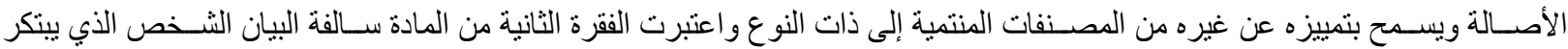

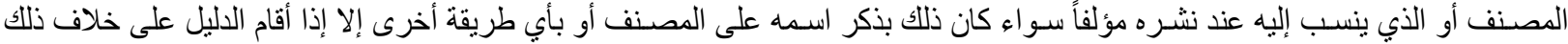

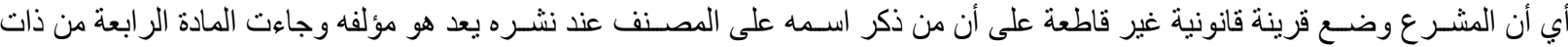

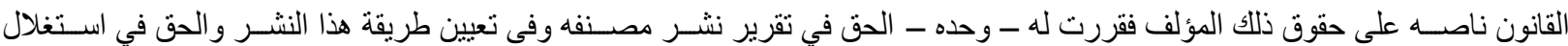

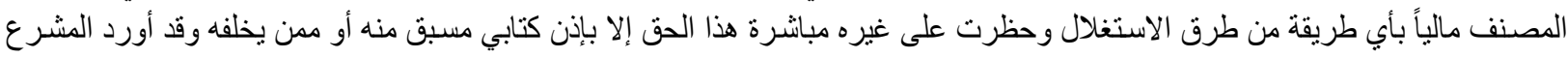

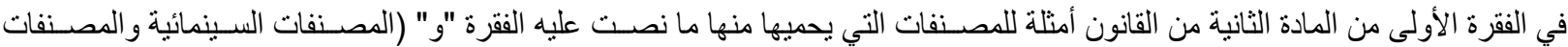

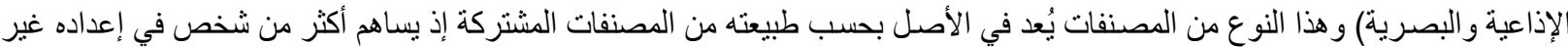

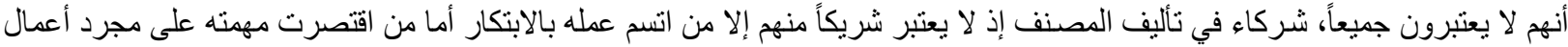

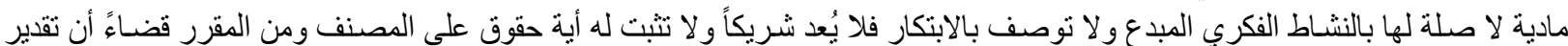

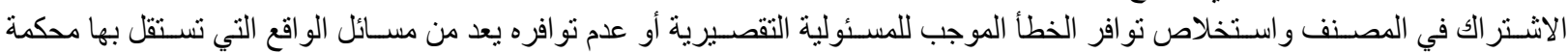

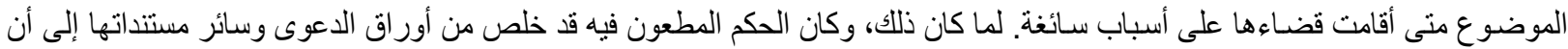

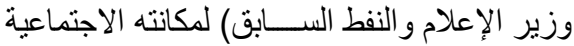

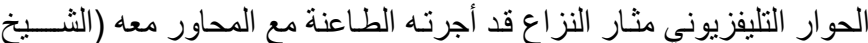

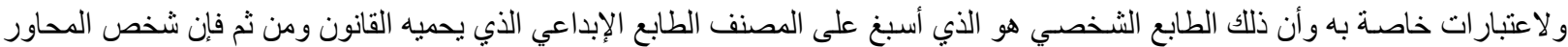

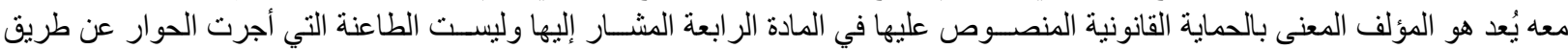

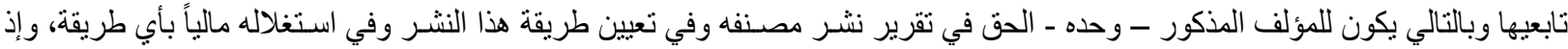

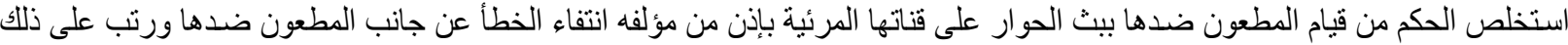

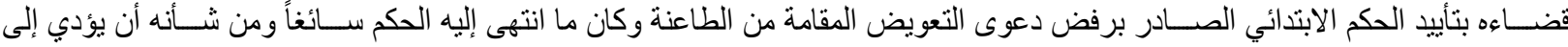

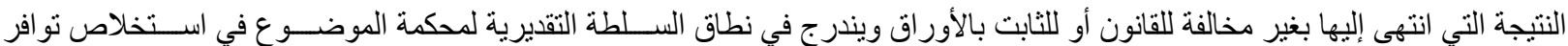

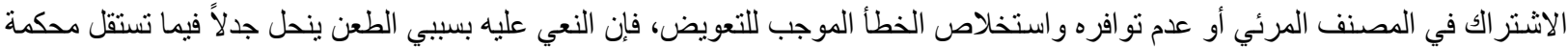

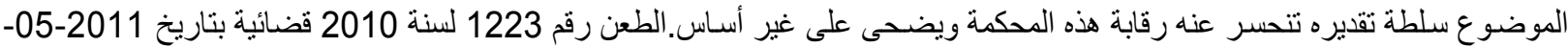

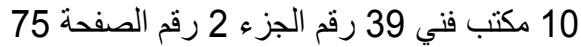


(و هو معيار موضوعي) و هذا المعيار ذاته مأخوذ به في مجال براءة الاختراع (42). إلا أنهما قد اعنبر العمل مبتكراً إذا كان قد تميز بطابع خاص غير معروف من قبل أو كان تجديـد العمل الموجود أو تطويره يتميز بطابع خاص. إلا أننا نرى أن الاعتماد على الجدة (المعيار الموضـوعي) في الابتكار أمر محل نقد، فالابتكار في مجال المصـنفات الأدبية و الفنية يعتمد على المعيار الثـخصـي وليس الموضـوعي، ويقصـــ بالمعيار الثـخصـي ذلك الطابع الذي يسـمح بتمييز المصنف عن سو اه من المصنفات المنتمية إلى نفس النوع (43)، بحيث لا يشترط أن يكون المصنف جديداً على نحو لم يصل إليه

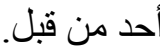

أما المذهب الثاني فيتبناه المشـرع الإمار اتي والعماني حيث يرى كليهما في الابتكار ذلك الطابع الإبداعي الذي يسبغ على المصــف الأصــالة والتمييز، بحيث ييرز شــصـية المؤلف ســواء في مقومات الفكرة التي عرضـهـا أو في الطريقة أو الأسلوب الذي اتبعه لعرض هذه الفكرة. وبمعني أخر البصمة الثخصية للمؤلف التي يضفيها على المصنف و التي تميز مصنفه عن غيره. وممـا لا شـــك فيه أن قانون حمـاية حقوق المؤلف يحمي الابتكار بهذا المعنى لا يحمي الجدة أو الحداثة لأن الأخيرة محمية بقانون بر اءة الاختر اع.

في حين جاء المذهب الثالث و الذي تبناه باقي المشـر عون الخليجيون بموقف مختلف عن الموقفين السـابقين، حيث لم

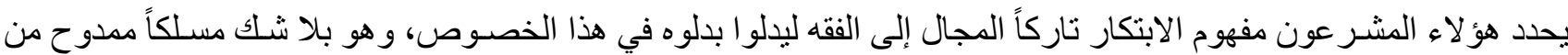
المشرع، فوضع التعريفات من المسائل التي يفضل تركها للفقه و القضاء دون التشريع. أما على الصـيد الفقهي فيمكن القول إن الفقه في غالبيته يري أن الابتكار هو البصـمة الثـخصية للمؤلف أو الإبداع

$$
\text { العقلي الذي بسبغ الأصالة والتمبيز على المصنف (44). }
$$

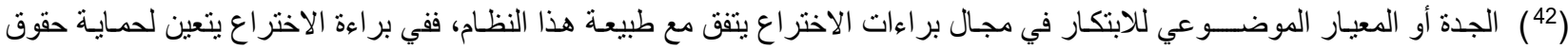

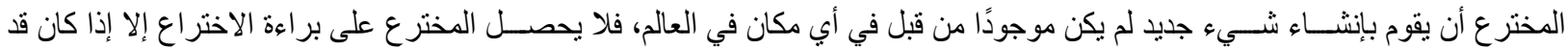

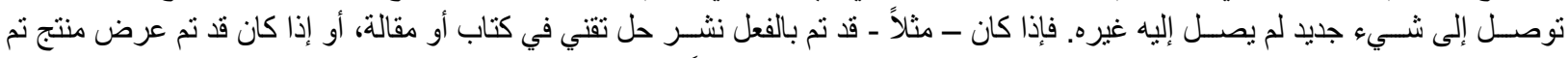

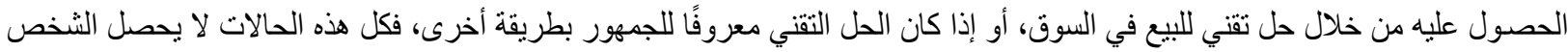

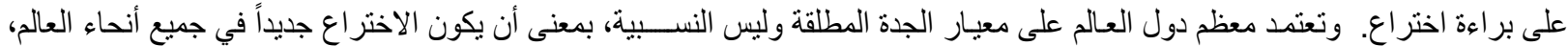

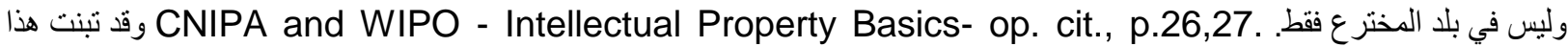

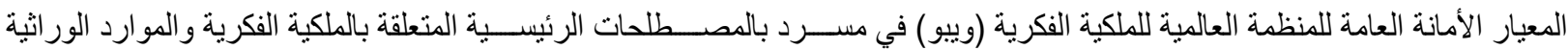

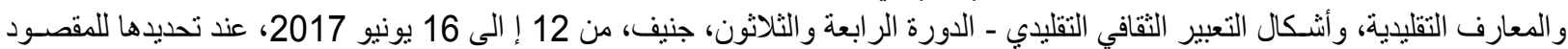

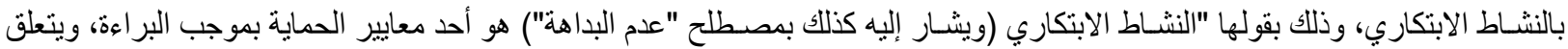

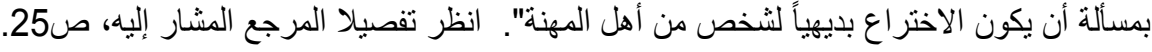

$$
\text { (43) }
$$

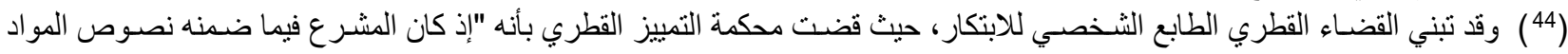

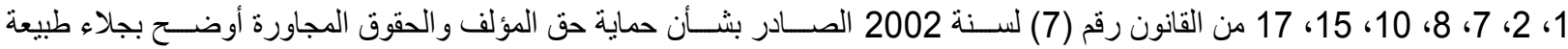

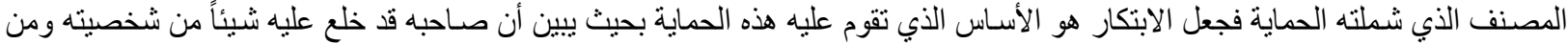

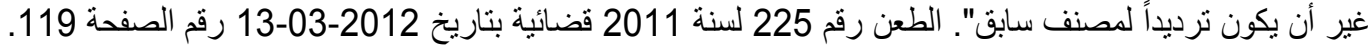

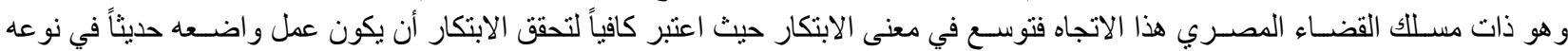

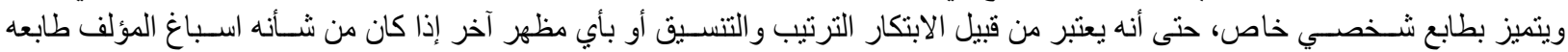

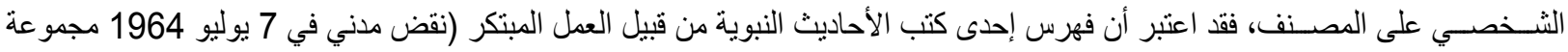
النقض المدني ســنة 1964، ص 92) مشــار إليه د. حســام الأهو اني - حماية حقوق الملكية الفكرية في مجال الإنترنت - بحث منشــور بموقع 
حيث ذهب هذا الر أي الى أن الابتكار يستلزم أن يكون للمؤلف دور يبرز شخصيته سو اء كان ذلك من حيث موضوع المصــف أم من حيث التعبير عن الفكرة و الطريقة التي يعالج بها هذه الفكرة. ويظهر ذلك بوضـوح من التعريفات التي أوردها فقهاء القـانون للابتكار، تللك التعريفات التي وإن اختلفت في الألفاظ فقد اتفقت في المعني ومن ذلك، تعريفهـ بـأنه " الطـابع الثخصـي الذي يعطيه المؤلف لمصنفه مما يسمح بتمييز المصنف عن غبره من المصنفات الأخرى "(45). ومنها تعريفه بأنه "

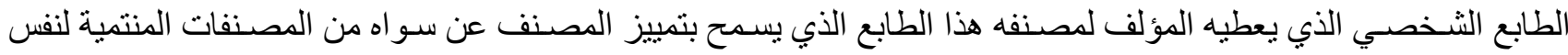

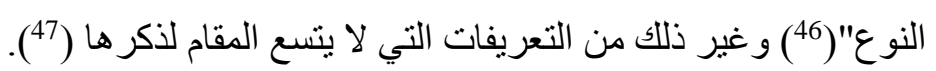
و على الخلاف من ذلك هنالك من الفقه من يقصر الابتكار على الجدة، فيري أن الابتكار بشكل عام يقصد به " وضع شيء جديد لم يكن موضوعاً من قبل"(48) أو هو " إيجاد شيء جديد لم يكن موجوداً من قبل أو اكتشاف شيء كان موجوداً ولكنه كان مجهو لاً و غير ملحوظ الوجود" (49). و الابتكار بهذا المعني يصــلح كعنصــر لحماية بر اءات الاختر اع، إلا أنه لا يصــلح كمعيار مميز للمصنفات المحمية بموجب قانون حماية حق المؤلف، ذلك القانون الذي يضفي الحماية على المصنفات التي يسبغ عليها المؤلف شخصيته وفكره.

\section{الغصن الثاني \\ صور الابتكار}

الابتكار - كما سـبق القول - شـرط ضـروري لحماية المصـفف، فالمصـفف الذي لا يتصـف بهذه الصـفة لا يحظى الصى بالحماية القانونية (50)، ولكن الابتكار لا يعني ابتداع شـيء جديد لم يصـل إليه أحد من قبل، وهو ما يطلق عليه " الجدة " و إنما

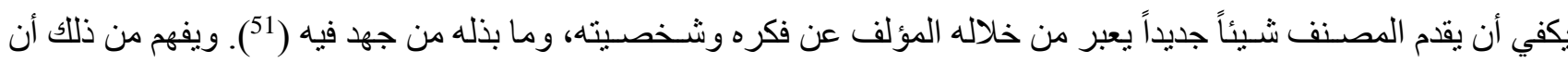
للابتكار صورتان، الأولي: الابتكار المطلق، والثانية: الابتكار النسبي،

الدليل الالكتروني للقانون العربي - www.arablawinfo.com- ص 5. نقض مدني ، جلســـ 178w/2/18، مكتب فني س 96 رقم 28،

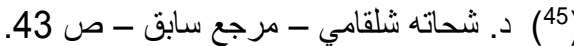

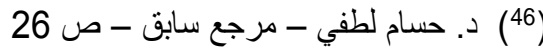

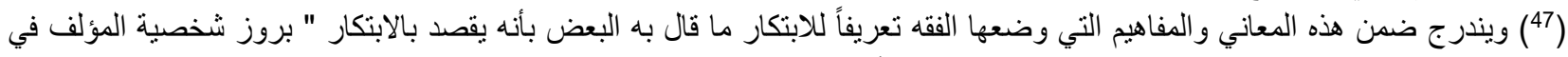

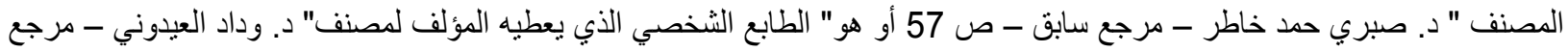

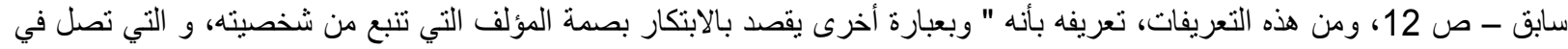

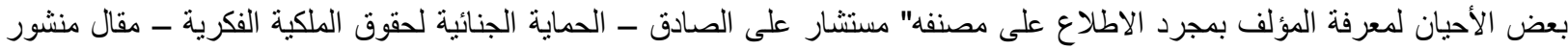

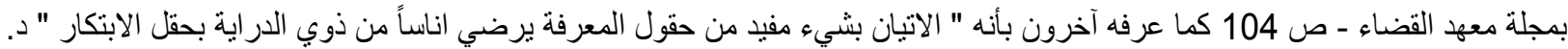

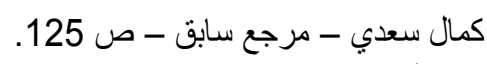

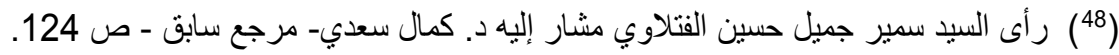

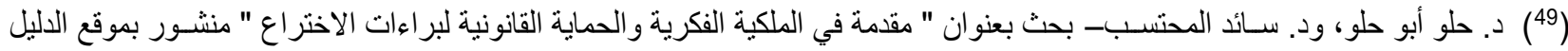

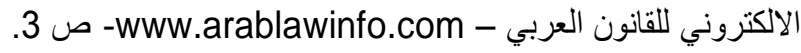

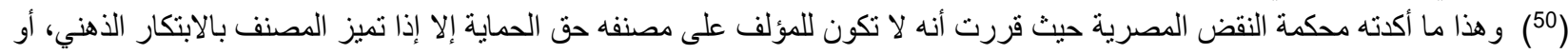

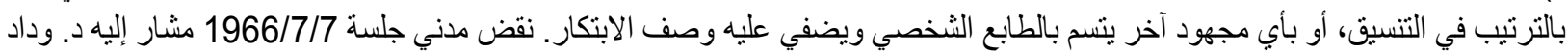

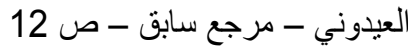

$$
\begin{aligned}
& \text { د. شحاته شلقامي - مرجع سابق - ص } 43 \text { ـابق } 43
\end{aligned}
$$


الهجلة الدولية لنشر البحوث والدراسات

International Journal of Research and Studies Publishing
لمجلد الثاني - الإصدار التاسع عشر تأريخ الإصدار: 20 مايو 2021م

$$
\text { ونستعرض فيما يلي هاتين الصورتين بإيجاز فيما يلي: - }
$$

أولاً: الابتكار المطلق: الابتكار المطلق هو ما يطلق عليه الجدة (52)، و الجدة تعني أن يضـع المؤلف مصـنفاً جديداً لا صلة له بمصنف آخر سابق، سو اء دن حيث الثكل أم التعبير أم الأسلوب (53)، فالجدة ابتكار، ولكنها ابتكار مطلق، فلا ريب أن

كل جديد مبتكر ، وليس كل مبتكر جديد (54).

ثانياً: الابتكار النسبي: و هذه الصورة من الابتكار يكفي لتحققها إبراز المؤلف شخصيته على المصنف، حتى لو كان

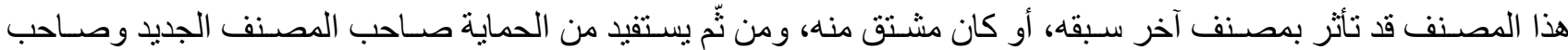
المصنف المبتكر ، فمن يبتكر تمثالاً دون أن يسبقه إلى ذلك أحد يعد مؤلفاً،

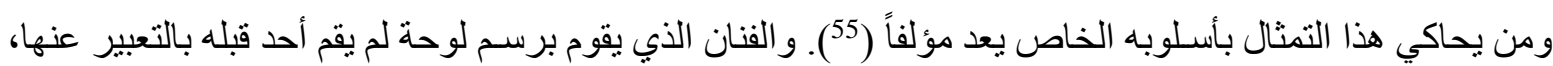

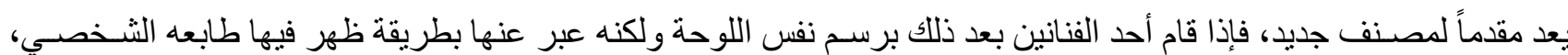
فلا تعتبر اللوحة الثانية جديدة، ولكنها تعتبر مبتكرة Original. وكذلك المســرحيـة المـأخوذة عن روايـة معينة يتمتع مؤلفها

بالحماية طالما أنها تعكس شخصيته (

و عليه يمكن القول إن المصنف يتمتع بالحماية القانونية، حتى ولو كان المؤلف قد استوحاه من مصنف سابق، طالما عبر فيه عن شخصيته، و أفكاره(57)

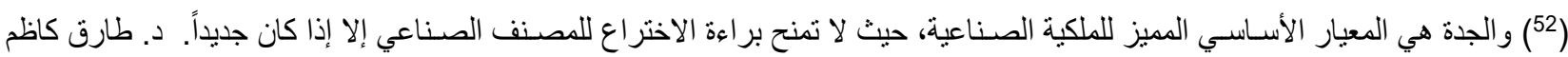

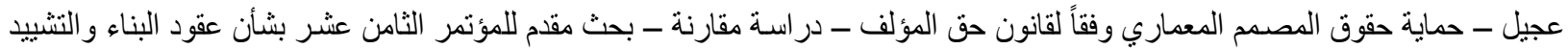

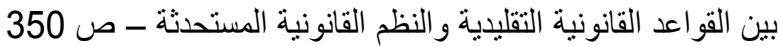

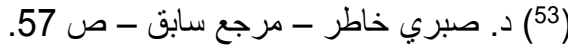

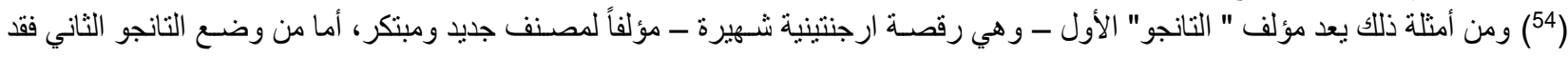

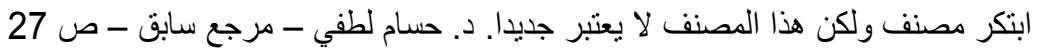
(55)

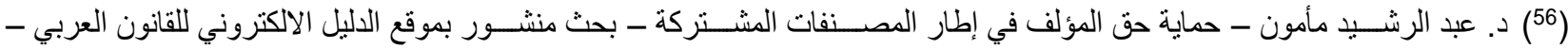
- www.arablawinfo.com

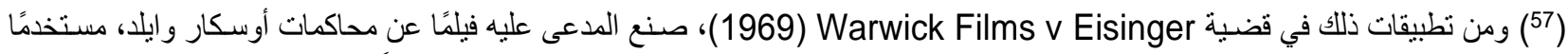

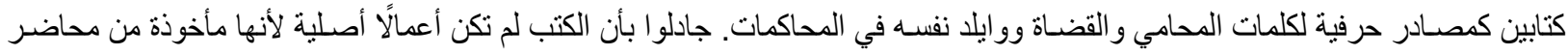

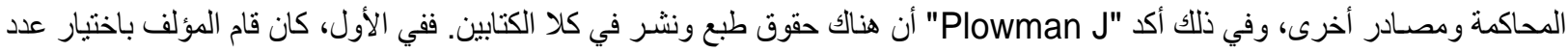

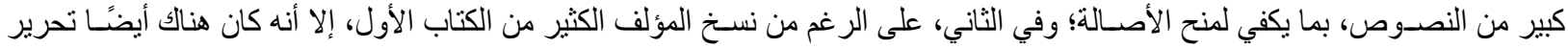

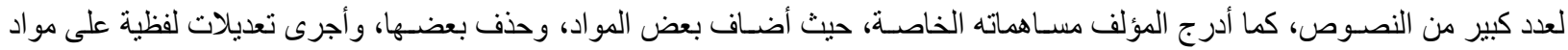

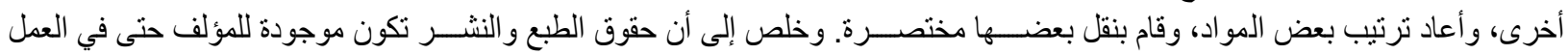

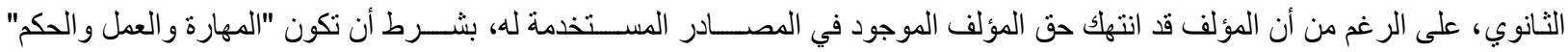

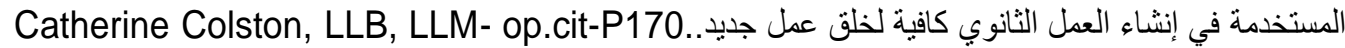




\section{الفرع الثاني \\ التعبيز عن المصنف}

تناولنا فيما سبق الثرط الأول من الثروط الو اجب تو افر ها في المصنف لبسط الحماية القانونية عليه، وقد تمثل هذا الثـرط في الابتكار، وسـنتناول في هذا المطلب الثـرط الثاني لإسـباغ الحماية القانونية على الإنتاج العقلي للمؤلف، ويتمثل هذا الثرط في التعبير عن المصنف.

ويمكن القول إنه يقصد بالتعبير عن المصنف خروج الفكرة الكامنة في النفس الى حيز الوجود بشكلها المحسوس (58)، لأن تلك الأفكار غير المعبرة عنها لا تعتبر مصنفاً (59). فالإنتاج الذهني المشمول بالر عاية ـ كما بينا سابقاً ـ هو الإنتاج المعبر عنه فقط، أي الذي خرج إلى حيز الوجود المادي، والمنفصل عن ذهن صاحبه، والذي يستطيع الغير أن بعلم به، أما الإنتاج الذهني الذي لا يخرج عن كونه أفكارًا تدور في ذهن صاحبها، فلا يعد مصنفاً، أيا كان قيمته، ومن ثُّم لا يصلح محلا للحماية القانونية.

و عليه لا يكون المصنف جديراً بالحماية القانونية إلا إذا تم التعبير عنه بأحد الوسائل المحسوسة (أي ثابت في وسط ملموس)(60). كالكتابة أو الصوت أو الرسم أو التصوير أو الحركة. أما الفكرة التي لم يتم التعبير عنها، فتبقى مجرد فكرة لا يقوم

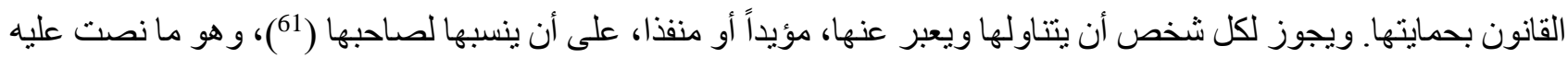
صر احة المادة الرابعة فقرة (أ) من قانون حماية حق المؤلف البحريني والتي جاء فيها أنه " لا نشمل الحماية ما يلي: أـ مجرد الأفكار ... ". يقابلها المادة الثالثة من قانون حقوق المؤلف الإمار اتي والتي نصت على أنه " لا نتمل الحماية الأفكار لكنها تتطبق على التعبير المبتكر عن أي منها". ويقابلها أيضا نص الفقرة 3 من المادة الرابعة من القانون القطري والتي جاء فيها أنه " لا تتمتع بالحماية المقررة بموجب هذا القانون ..... 3 ـ الأفكار و الإجراءات و أساليب العمل والمفاهيم الرياضية، و المبادئ و الحقائق المجردة، ومع ذلك بعتبر المبتكر عن أي منها مشمو لاً بالحماية".

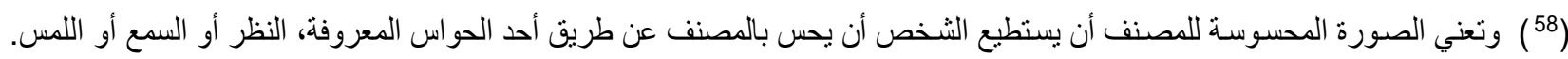

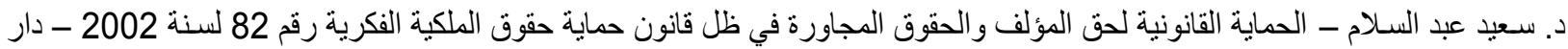

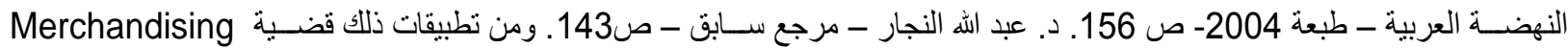
Adam Ant " Corp of America v Harpbond

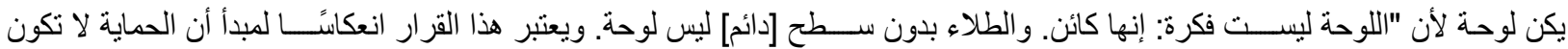

Catherine Colston, LLB, LLM- op.cit-P169 للأفكار، وإنما تكون للتعبير عن الأفكار.

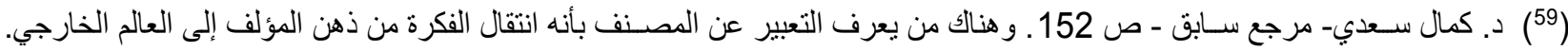

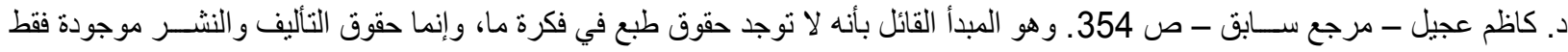

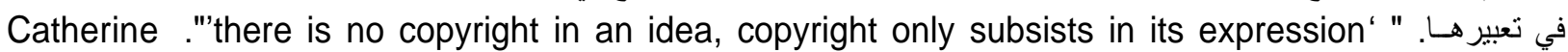
Colston, LLB, LLM- op.cit-P174.

${ }^{(60)}$ Deborah E. Bouchoux -ntellectual Property - op-cit- p.194.

$$
\text { رأى د. عبد الرزاق السنهوري مشار إليه د. كمال سعدي- مرجع سابق - ص } 153 .
$$


وقد سـاوى المشـرع الخليجي بين وسـائل التعبير عن المصـنف فنص صـر احة على حماية المصـنفات أيا كان شـكل التعبير عنها، ففي التثـريع البحريني نجد المادة الثانية من قانون حماية المؤلف تتص على أن " تتمتع بالحماية المقررة بموجب أحكام هذا القانون المصــنفات الأدبية والفنية و العلمية بمجرد ابتكار ها، دون حاجة إلى أي إجر اء شــــلي، أيا كانت قيمة هذه إنه المصنفات أو نوعها أو غرضها أو طريقة أو شكل التعبير عنها ........ و هو ذات مـا قرره المشــرع الكويتي - مع اختلاف الصـــاغة ـ في المادة الثالثة من قانون حقوق الملكية الفكرية، و التي جـاء فيها أنه " تســري الحمـايـة التي يقرر ها هذا القانون لحقوق المؤلفين على المصـــفات المبنكرة في الآداب و الفنون و العلوم أبا كان نوع هذه المصــفات أو طريقة التعبير عنها أو أهميتها أو الغرض من تأليفها أو تصــنيفها بمجرد ابتكار هادون الحاجة إلى أي إجر اء شـــلي". قريب من ذلك نص المادة الثانية من قانون حق المؤلف العماني و التي نصـــت على أن " تتمتع بالحماية بموجب أحكام هذا القانون المصنفات الأدبية والفنبة و العلمية المبتكرة بصرف النظر عن قيمة تللك المصنفات أو نوعها أو طريقة التعبير عنها أو الغرض من تأليفها ". و المادة الثانية من قانون حماية حقوق المؤلف القطري و التي تضــــت النص على أنه " يتمتع بالحماية المقررة في هذا القانون مؤلفو المصنفات المبتكرة في الآداب والفنون، أيا كانت قيمة هذه المصنفات أو نو عيتها، أو الغرض من نأليفها، أو طريقة التعبير عنها". كذللك ورد ذات الحكم في نظـام حمـايـة حقوق المؤلف الســـودي، في المـادة الثانية منـه، و التي جاء فيها أنه " يتمتع بحماية هذا النظام مؤلفو المصـنفات المبتكرة في العلوم والآداب و الفنون أيا كان نوع هذه المصـنفات أو طريقة التعبير عنها أو أهميتها أو الغرض من تأليفها ". ولم يكتف المشرع السعودي بالنص على ذلك بل أثنار إلى وسائل التعبير عن المصنف المحمي وذلك في المادة الثالثة من ذات القانون و التي نصــت على أنه "تثــــل الحماية بوجه عام مؤلفي المصــنفات التي يكون مظهر التعبير عنها الكتابة أو الصوت أو الرسم أو التصوير أو الحركة". ولم يرد مثل هذا النص في القانون الإمار اتي، إلا أن ذلك لا يعني استلز ام المشـرع شكل معين للتعبير عن المصنف المحمي، فقد اكتفى المشرع الإمار اتي للتأكيد على المسـاو اة بين وسـائل التعبير عن المصنفات بتضمينها تعريف المصنف ذاته، حيث قرر أنه يقصد بالمصنف: كل تأليف مبتكر في مجال الآداب، أو الفنون، أو العلوم، أيا كان نوعه أو طريقة التعبير عنه، أو أهميته أو الغرض منه.

\section{ويمكن الإثارة بايجاز لأهم وسائل التعبير عن المصنف (62) فيما يلي:}

الوسـيلة الأولى: الكتابة (63): و الكتابة بلا شـك من أهم وسـائل التعبير عن المصـنفات، ونشــرها على نحو يتيح للجمهور الاطلاع عليها، و هي تظهر في كافة أنواع المصنفات سواء أكانت علمية أم أدبية أم فنية، وسواء تعلقت بمجال التاريخ أو الفلسفة أو القانون أو السياسة أو الموسيقي وغير ذلك.

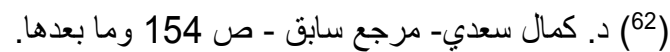

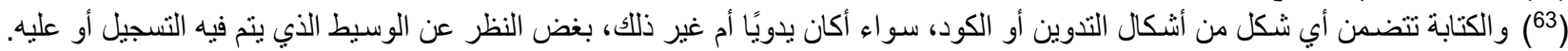

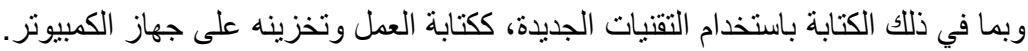

Catherine Colston, LLB, LLM- op.cit-P169 
المجلة الدولية لنشر البحوث والدراسات

International Journal of Research and Studies Publishing
المجلد الثاني - الإصدار التاسع عشر تأريخ الإصدار: 20 مايو 2021م

الوسيلة الثانية: الصوت: ويعد الصوت الوسيلة الثانية للتعبير عن الإبداع العقلي وطريقة من طرق نشر المصنف و إتاحته للجمهور ومن مظاهر اســتخدام الصــوت كوسـيلة للتعبير عن المصــف، الألقاء الثـفهي. كالخطب و المحاضــرات و المو اعظ و الدروس و الآر اء الخاصة في المناقثنات و الندوات وما يمانلها. ومن ذلك أيضا عزف الموسيقي و التمثيل. الوسيلة الثالثة: الرسم والتصوير والنحت: وهي أيضاوسائل للتعبير عن المصنفات، يستوي أن ينم ذلك عن طريق

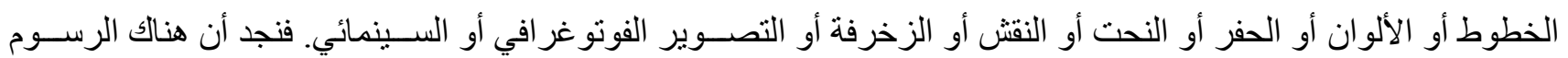
التخطيطية و الخر ائط و الرسوم البيانية و الخر ائط و التصاميح و الرسوم الزينية و المائية و الخشبية وما بماتلها.

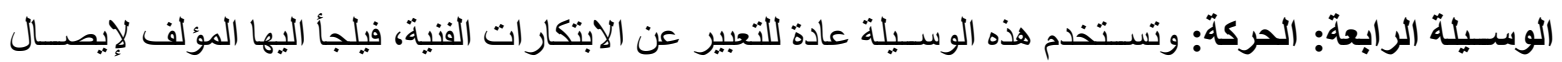
مصنفه الى الجمهور، و هو ما نجده في فنون الرقص و الباليه و التمثيل و الألعاب كألعاب الكار اتيه وما يماتلها.

\section{المطلب الثالث \\ أحكام المصنف المشترك}

لقد أثنارت المصنفات المشنركة العديد من الإشكاليات التي تتعلق بتحديد أحكام هذا النوع من المصنفات، ومن ذلك الآتي، ما هو القدر الذي يقع عليه حق كل من المشتركين في المصنف المشترك؟ وهل يجوز لكل شريك أن يقوم باستغلال أدائه

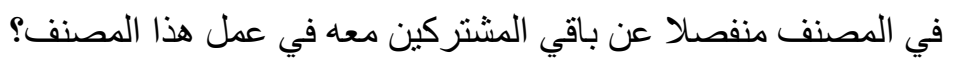
عالجت التشريعات الخليجية هذه الإشكالية، مفرقة بين فرضين، الفرض الأول: الاشتر اك المطلق، ويتمثل هذا الفرض في حالة اثتر الك أكثر من مؤلف في إعداد المصنف على نحو يتعذر معه تحديد نصيب كل منهم في العمل المشترك، أما الفرض في الثاني: الاثتر الك النسبي فيتمثل في حالة إمكان فصل نصيب كل مشترك في هذا المصنف عن نصيب غيره. وهو ما سنتناوله فيما يلي، ونختم هذا المطلب بالتعرض للأحكام المشتركة بين نوعي المصنف المشترك، لذا رأينا أن نتبع التقسيم التالي: الفرع الأول: أحكام الاشتر اك المطلق. الفرع الثاني: أحكام الاشتر اك النسبي. الفرع الثالث: الأحكام المشتركة بين نوعي المصنف المشترك

\section{الفرع الأول}

أحكام الاشترا(ك المطلق

الاشتر الك المطلق يعني ذوبان شخصية جميع المؤلفين في المصنف على نحو لا يمكن الفصل فيه بين إساهم و إبداع كل منهم، وفى هذا النوع من الاشتر الك، يقوم أكثر من مؤلف بالاشتر اك في تأليف مصنف، فيمتزج كل عمل بالآخر، كحالة المصمم المعماري الذي يشترك معه آخر في تصميم نموذج مصغر لمبني، و النحات الذي يشترك مع آخر في نحت تمثال (64).

(64) ويدخل برنامج الحاسب الآلي في هذه النوعية من المصنفات فلا بمكن فصل عمل أحد المؤلفين عن الآخر فضلا عن صعوبة التمييز بينهم،

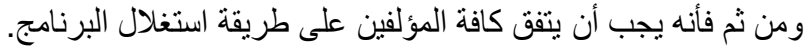


ويمكن استظهار أحكام المصنف المشترك المطلق من خلال عرض نصوص التشريعات الخليجية بهذا الخصوص، ففي التشريع البحريني نجد أن المادة 32 فقرة 1 قد نصت على أن " إذا ساهم أكثر من شخص في تأليف مصنف مشترك، اعتبر الجميع أصحاب الحق في المصنف بالتساوي فيما بينهم، ولا يجوز لأحدهم الانفر اد بمباشرة حقوق المؤلف بشأن هذا المصنف، وذللك كله ما لم يتفق كتابة على خلافه"، وهو ذات ما قرره المشرع العماني بقوله " كل من ساهم في تأليف مصنف مشترك على نحو لا يمكن معه فصل مساهته فيه عن مساهمة باقي الثركاء، يكون صاحب حق على المصنف بالتساوي مع باقي الثركاء، ولا يجوز لأحد الثركاء الانفر اد بمباثرة حقوق المؤلف على هذا المصنف، ما لم يتفق كتابة على غير ذلك." (المادة 21 من

$$
\text { قانون حق المؤلف العماني). }
$$

قريب من ذلك ما قرره المشـرع الكويتي في المادة 26 من قانون حق المؤلف و الحقوق المجاورة لسنة 2019، بقوله "يعتبر كل مؤلف في المصنف المشترك شـريكاً بالتشـاوي في الحقوق المالية ما لم يتفق كتابة على غير ذللك، وفي هذه الحالة لا يجوز لأي منهم الانفر اد بمباثرة حقوق المؤلف إلا باتفاق مكتوب"(65).

كما تقرر ذات الحكم في المادة 25 فقرة 1 من التشريع الإمار اتي والتي جاء فيها " اذا اثترك عدة أشخاص في تأليف مصنف بحيث لا يمكن فصل نصيب أي منهم عن الأخر اعنبر جميع الثركاء مؤلفين للمصنف بالتساوي فيما بينهم، ما لم يتفق

كتابة على غير ذللك، وفي هذه الحالة لا يجوز لأحدهم الانفر اد بمباشرة حقوق المؤلف إلا باتفاق مكتوب مسبق بينهم"، و هو ذات ما قرره المشرع القطري مع اختلاف الصياغة حيث نص في المادة 33 فقرة 1 على أنه" إذا اشترك عدة أثخاص في تأليف مصنف، يكون المؤلفون المشاركون هم المالكون الأصليون للحقوق المالية في ذلك المصنف. و لا يجوز لأحد الشركاء منفرداً مباشرة الحقوق المترنبة على حق المؤلف، إلا باتفاقهم جميعاً كتابة. و إذا وقع خلاف بينهم يكون الفصل فيه من اختصاص القضاء. ولكل من المشتركين في التأليف الحق في رفع الدعوى عند وقوع أي اعتداء على حق المؤلف. كما ينتقل ذلك

$$
\text { الحق إلى ورثثة أب منهم". }
$$

و هي ذات الأحكام التي قرر ها نظام حقوق المؤلف السعودي في المادة التاسعة فقرة 1 و التي جاء فيها أنه "إذا اثنرك عدة أنــاص في تأليف مصـنف بحيث لا يمكن فصـل دور أي منهم في المصـنف يعتبرون جميعاً شـركاء بالتسـاوي في ملكية المصنف، و لا يجوز لأي منهم منفرداً مباثرة حقوق المؤلف المقررة بمقتضى هذا النظام ما لم يتلق كتابة على خلاف ذلك". ويتضح مما سبق أن الأحكام التي يخضع لها هذا النوع من المصنفات تتلخص في الآتي: 1 - حقوق المؤلف مملوكة لكافة المشاركين في العمل، والأصل، في هذا النوع من الاشتر الك، أن يكون نصبب كل مؤلف مشترك في ملكية المصنف مساويا لنصيب بقية الثركاء. 2 - لا يجوز لأي مؤلف مشارك في إعداد المصنف أن ينفرد بمباشرة الحقوق المترتبة عليه، فمثلاً، لا يجوز نشر العمل، إذا لم يكن قد نشر فعلا، و لا يجوز تعديله أو استخدامه بشكل مختلف عن النشر الأول دون مو افقة جميع المؤلفين المشاركين. ومع ذلك في حالة الرفض غير المبرر لواحد أو أكثر من المؤلفين المشاركين،

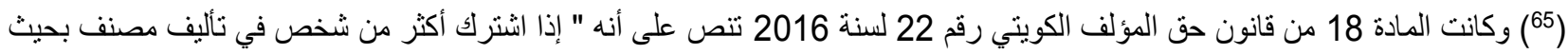

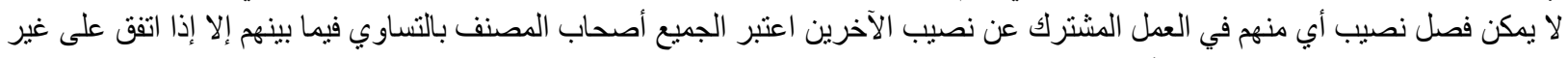

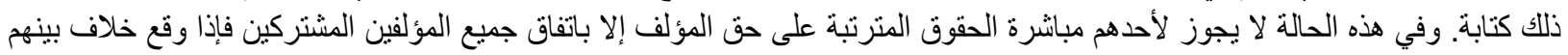


وكان من شأن هذا الرفض الإضرار باستغلال المصنف، جاز لصاحب المصلحة اللجوء إلى المحكمة المختصة لاستصدار تصريح بالنشر أو التعديل أو الاستخدام الجديد للمصنف، ومرجع ذلك أن هذا النوع من المصنفات يستلزم الإدارة المشتركة من قبل كافة المؤلفين، وليس الإدارة المنفردة أو المنفصلة، ومن ثِّم بلزم لمباثرة الحقوق المترتبة عليه أن بكون ذلك بإجماع آراء

$$
\text { المؤلفين(66). }
$$

3 - الأحكام السابقة لبست من النظام العام فيجوز للمؤلفين في المصنف المشترك الاتفاق على خلافها، فيجوز مثلا

الاتفاق على أن يكون نصيب كل مؤلف مختلف عن نصيب الآخر، كما يجوز الاتفاق على أن تكون إدارة المصنف بالأغلبية وليس الأجماع، أو يتم تفويض أحدهما في إدارة المصنف واستغلاله، على أن أغلب التشريعات، محل المقارنة، قد اشترطت للاتفاق على خلاف ما ورد من أحكام متعلقة باستغلال المصنف المشترك، أن يتم هذا الاتفاق كتابة( 4 - يجوز للمؤلف المطالبة ـ وفقاً للقو اعد العامة في القانون ـ منفرداً بالتعويض عن الضرر الذي لحقه، إذا كان هناك أي مساس بالحقوق المعنوية الخاصة به (68.)، لأن الضرر الذي يصيبه ما هو إلا ضرر شخصي، و إن نجم عن المساس بالمصنف المشترك.

الخلاصة أن في مثل هذا النوع من المصنفات المشتركة يجب استيفاء شرطين. الأول موضوعي: ويتمثل في عدم التمييز و عدم الانفصال بين مساهمات المؤلفين، والثرط الثاني: شرط شخصي، يتمثل في اتجاه إر ادة المؤلفين، ومو افقتهم، على هولى أن العمل المشترك الذي يجمعهم هو شيء أكثر من مساهمة شخصين تم تجميعهما معًا، أب أن إرادتهم قد اتجهت إلى إيجاد كيان جديد و احد يمثل شينًا أكثر من مجرد مجموع المساهمات الأولية للمؤلفين(69).

\section{الفرع الثاني}

أحكام الاشتراك النسبي

يقصد بالاشتر اك النسبي اشتر اك أكثر من مؤلف في تأليف المصنف على نحو لا يندمج نصيب كل منهم بالآخر وبحيث يمكن تمييز مساهمة كل منهم وفصله عن مساهمة الآخر.

$\left({ }^{66}\right)$ Thomas Margoni \& Mark Perry - OWNERSHIP IN COMPLEX AUTHORSHIP: A COMPARATIVE STUDY OF JOINT WORKS IN COPYRIGHT LAW-2011 https://papers.ssrn.com/sol3/papers.cfm?abstract_id=1992610- p.3.

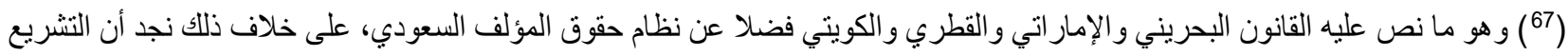

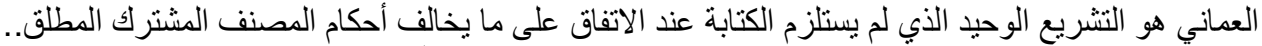

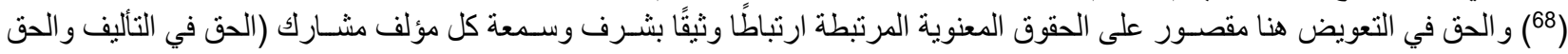

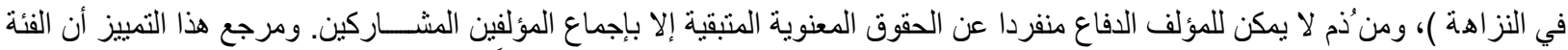

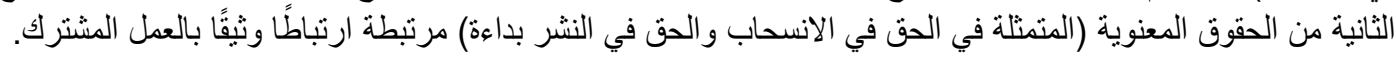

Thomas Margoni \& Mark Perry - op.cit- p.5.

$\left.{ }^{(69}\right)$ Thomas Margoni \& Mark Perry - op.cit- p.4. 
ومن أمثلة ذلك اشتر اك أكثر من شخص في تأليف كتاب نسب كل جزء من أجزائه إلى من كتبه أو عندما يشترك عدد من الأشخاص في أغنية فيكون أحدهم كاتباً للكلمات والآخر ملحناً (العمل الموسيقي المصحوب بكلمات)، والأعمال الدرامية(70)

$$
\text { و غير ها من الأعمال المركبة (71). }
$$

ويمكن استظهار أحكام الاشتر اك النسبي من خلال استعر اض نصوص التشريعات الخليجية في هذا الخصوص، حيث تضمن التشريع البحريني النص على أن "إذا كانت مساهمة كل من المؤلفين في المصنف المشترك تتدرج تحت نوع مختلف من الفن ومميزة بحيث يمكن فصلها، كان لكل منهم الحق في استغلال الجزء الذي ساهم به على حدة بشرط ألا يضر ذلك باستغلال المصنف المشترك، ما لم يتفق كتابة على غير ذلك". (مادة 32 فقرة 2 من التشريع البحريني بشأن حماية حقوق المؤلف و الحقوق بهري المجاورة).

قريب من ذلك نص المادة 25 فقرة 2 من التشريع الإمار اتي، و التي جاء فيها أنه " فإذا كان اشتر الك كل من المؤلفين يندرج تحت نوع مختلف من الفن داخل ذات المصنف، كان لكل منهم الحق في استغلال الجزء الذي ساهم به على حدة، بشرط الا يضر ذللك باستغلال المصنف بالنسبة للباقين ما لم يتفق كتابة على غير ذلك". و المادة التاسعة فقرة 2 من النظام السعودي، و التي نصت على أن "إذا اشترك عدة أثناص في تأليف مصنف بحيث يمكن فصل دور كل منهم في المصنف المشترك، كان لكل منهم الحق في استغلال الجزء الخاص به على حدة بشرط ألا يضر ذلك باستغلال المصنف المشترك ما لم بتفق على غير ذلك".

كذللك وردت ذات الأحكام في المادة 33 فقرة 2 من القانون القطري، و التي جاء فيها أنه " و إذا اشترك عدة أشخاص في تأليف مصنف مشترك، كان لكل منهم الحق في استغلال الجزء الخاص به على حدة، وبشرط ألا يضر ذلك باستغلال المصنف، ما لم يتفقو ا على غير ذلك". و هو ما تضمنته أيضا ـ مع اختلاف الصباغة ـ المادة (21) من القانون العماني و التي نصت على أنه " ..... وفي الحالة التي تندرج فيها مساهمة كل من المؤلفين الثركاء تحت نوع مختلف من الفن على نحو يمكن معه فصل مساهمة كل منهم عن مساهمة الآخرين، يكون لكل منهم الحق في استغلال الجزء الذي ساهم به على حدة شريطة ألا يكون ذلك من شأنه الإضر ار باستغلال المصنف المشترك، ما لم يتفق كتابة على غير ذلك. ". ووردت ذات الأحكام أيضا في المذكرة الإيضاحية للقانون الكويتي رقم 75 لسنة 2019 الخاص بحقوق المؤلف

$\left({ }^{70}\right)$ Deborah E. Bouchoux -ntellectual Property - op-cit- p.195.

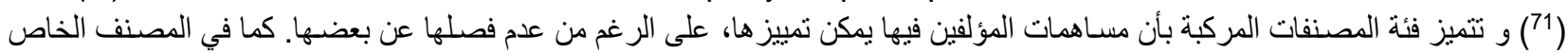

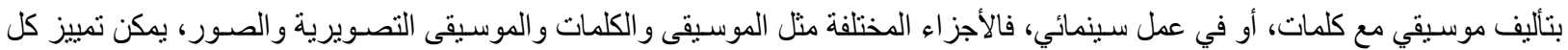

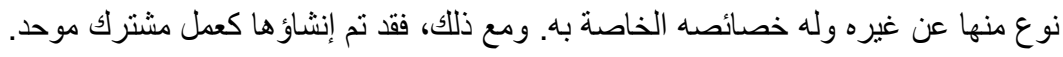

Thomas Margoni \& Mark Perry - op.cit- p.4.

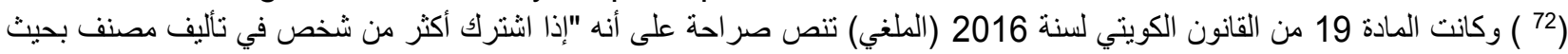

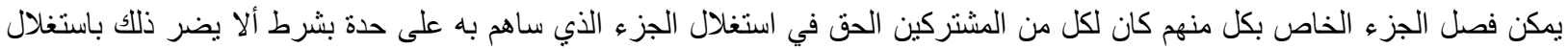

المصنف المشترك ما لم يتفق على غير ذللك كتابة". 
المجلة الدولية لنشر البحوث والدراسات

International Journal of Research and Studies Publishing
المجلد الثاني - الإصدار التاسع عشر تأريخ الإصدار: 20 مايو 2021م

\section{وبناء على هذه النصوص يتضح الآتي:}

1 - أن لكل شريك الحق في أن ينفرد في استغلال الجزء الذي ساهم به(73)، وذلك ما دام هذا الجزء لا يندمج مع غيره، فيكون له الحق في استخدامه، و إعداد أعمال مشتقة منه، وتنفيذه، و عرضه، و غير ذلك من صور الاستغلال المالي، وذلك دون

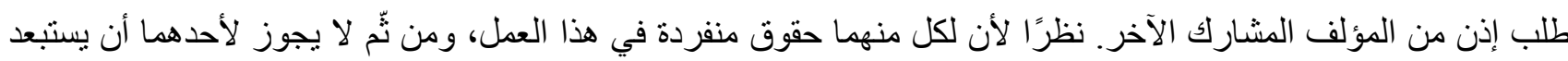
الآخر من استخدام العمل أو ممارسة حقوق المؤلف على الجزء الخاص به(74)، بشرط عدم الإضرار بالمصنف المشترك كمالو ساهم المشترك بنصيبه في مؤلف مشابه (75). وقد ورد هذا الحكم في كافة التشريعات محل المقارنة، مع ملاحظة أن هذا الحكم ليس من النظام العام، فيجوز الاتفاق على خلافه.

2 - أن التشريعات الخليجية - محل المقارنة ـ قد انقسمت إلى قسمين فيما يتعلق باشتر اط الكتابة من عدمه، حيث

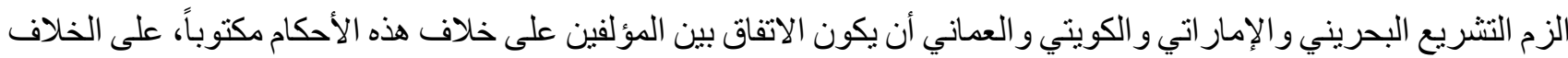
من ذلك لم يشترط المشرع السعودي و القطري الكتابة في هذه الحالة.

\section{أحكام مشتركة بين نوعي المصنف المشترك}

بادئ ذي بدء، يجدر الإشارة إلى أن هنالك أحكاما تسري على نوعي المصنف المشترك وهذه الأحكام سنتعرض لهام بايجاز في النقاط التالية:

\section{أو لاً - الحق في رفع الاعاوي لحماية حقوق المؤلف في المصنف المشترك:}

و هذا الحق مكفول لكافة المؤلفين فر ادى أو جماعة، وهو ما قررته الفقرة الثانية من المادة 32 من التشريع البحريني بقولها " ولكل من الثركاء في المصنف المشترك الحق في رفع دعوى أمام المككة المختصة لاتخاذ أية إجر اءات تحفظية أو لمنع التعدي على أي من حقوق المؤلف بشأن هذا المصنف". و هو ذات ما قررته الفقرة 3 من المادة (25) من التشريع الإمار اتي بقولها " ولكل منهم الحق في رفع الدعاوى عند وقوع اعتداء على اي حق من حقوق المؤلف المحمية بهذا القانون". ولا يختلف التشريع القطري في تقرير ذلك الحق عن التشريعين البحريني و الإمار اتي إلا في الصياغة، حيث نصت المادة 33 فقرة (1) من التشريع القطري على أنه" .. ولكل من المشتركين في التأليف الحق في رفع الدعوى عند وقوع أي اعنداء على حق المؤلف. كما ينتقل ذلك الحق إلى ورثنة أي منهم".

ومن الجدير بالذكر في هذا الإطار أن القانون العماني و الكويني (76)، ونظام حقوق المؤلف السعودي لم يرد فيهما ثمة ذكر لمثل هذه الأحكام.

$\left({ }^{73}\right)$ Thomas Margoni \& Mark Perry - op.cit- p.3.

$\left({ }^{74}\right)$ Deborah E. Bouchoux -ntellectual Property - op-cit- p.230.

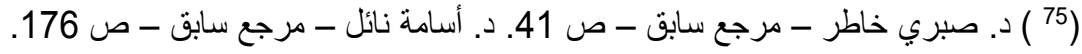

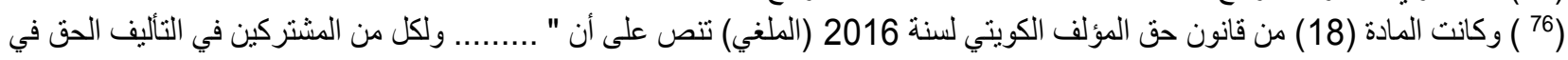

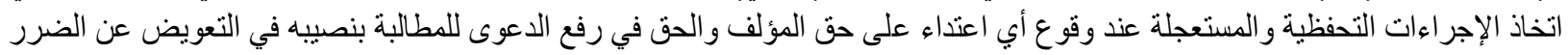


ويستفاد من ذلك أنه يجوز للثريك - في بعض التشريعات الخليجية ـ الانفر اد باتخاذ الإجر اءات المستعجلة عند وقوع أي اعتداء على حق المؤلف، مثل الإجر اءات التحفظية أو منع التعدي. (القانون البحريني و القطري و الإمار اتي). ثانياً _- انتقال حقوق المؤلف المالية على المصنف المشترك: في حالة وفاة أحد الشركاء في المصنف المشترك ـ أيا كان نوع الاشتر اك - تنتقل حقوقه إلى ورثثه، أما إذا توفى أحد المؤلفين الثركاء دون أن يترك ورثنة، فقد اختلف حكم هذه الحالة بين التشريعات الخليجية فهناك من قرر أنه، يؤول الجزء الخاص به إلى باقي الثركاء أو خلفه((77)، و هناك من قرر أن نصيب الثريك المنوفى يؤول إلى المجلس الوطني للتقافة و الفنون

و الآداب(78) و هناك أخير ا من قرر أنها تؤول إلى من يستحقه حسب أحكام الثريعة الإسلامية(79). ولكن هذه التشريعات - باستثناء النظام السعودي ـ قد أجازت الاتفاق على خلاف الحكم السابق، على أن يكون هذا

الاتفاق كتابة.

\section{ثُالثاً ـ مدة حماية حقوق المؤلف المالية على المصنف المشترك:}

حرصت التشريعات الخليجية على تحديد مدة حماية لحقوق المؤلف في المصنفات المشتركة، يستوى أن يكون لاشتر الك مطلق أو نسبي، و هذه الحماية لا تقتصر على مدة حياة المؤلفين المشتركين، و إنما امتدت أيضا إلى ورثته،، وكانت مدة هذه الحماية في أغلب هذه التشريعات خمسين سنة تبدأ من أول السنة التالية لوفاة آخر المؤلفين، هذا فضلا عن مدة حياة المؤلف ذاته، و هو ما تقرر صر احة في التشريع الإمار اتية(80)، و القطري(81)، و الكويتي(82)، و العماني(33). في حين نجد أن نظام حماية المؤلف السعودي قد اتفق مع التشريعات السابقة في المدة، واختلف معها في بداية حماية

هذه الحقوق بعد وفاة المؤلف، حيث جعل بدايتها اعتبار ا من ناريخ وفاة آخر من بقي حيا من مؤلفي المصنفات المشتركة(84).

(77 ) وقد ورد هذا الحكم في المادة 21 من القانون العماني، يقابلها المادة 25 من القانون الامار اتي.

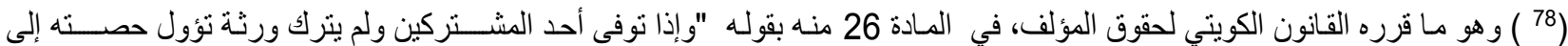

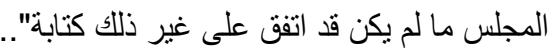

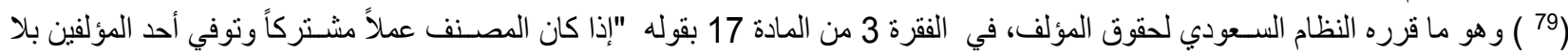

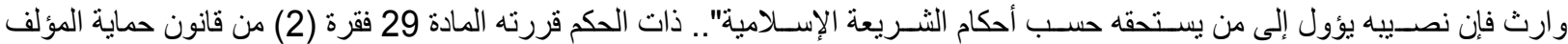

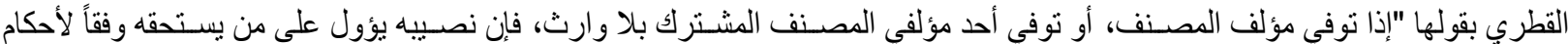
الثريعة الإسلامية".

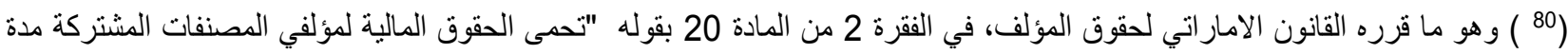

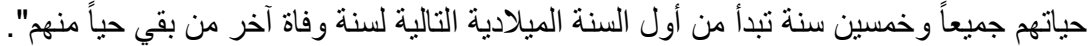

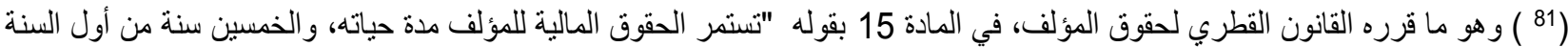

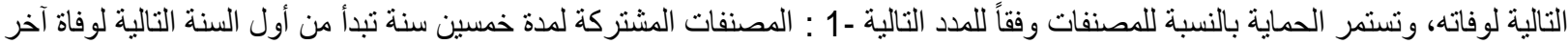

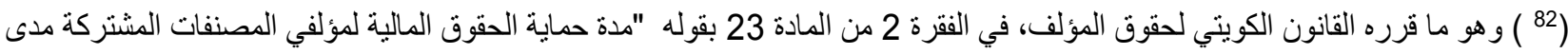

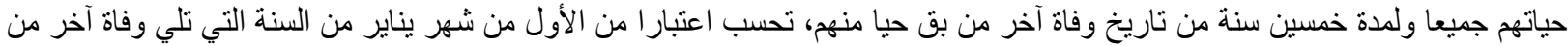
بقي منهر على قبيد الحياة". (83 ) و هو ما قرره القانون العماني لحقوق المؤلف، في المادة 27 بقوله " تحمى الحقوق المالية لمؤلفي المصنفات المشتركة مدة حياتهم وسبعين

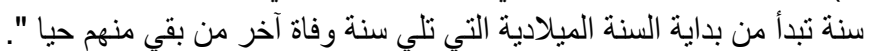

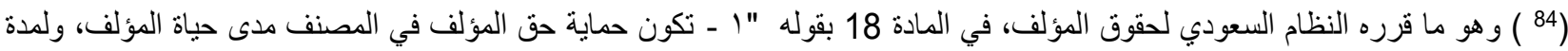

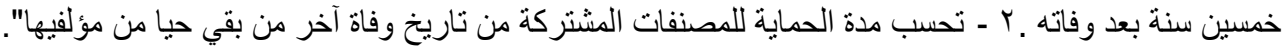


و اختلف التشريع البحريني في مدة الحماية المقررة لحقوق مؤلفي المصنفات المشتركة، فجعلها أطول من نظر ائه، مع اتفاقه معهم في بداية الحماية عقب وفاة المؤلف، حيث قرر في المادة (38) بحريني أن الحقوق المالية لمؤلفي المصنفات المشتركة تخضع لحماية مدة حياتهم جميعا، وسبعين سنة تبدأ من أول السنة الميلادية التالية لسنة وفاة آخر من بقي حيا منهم.

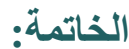

بعد هذا العرض لا يسعنا في الخاتمة إلا أن نبرز أهم النتائج والتوصيات التي انتهينا إليها، و هي كالآتي:

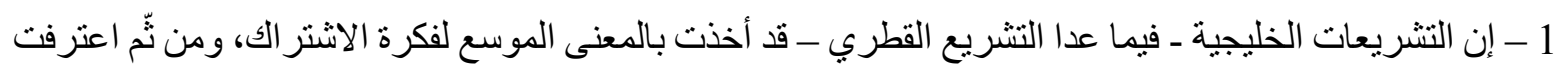
بنو عين من الاشتر اك و التعاون في ابتكار المصنف، الاشتر اك المطلق، والاشتر اك النسبي في حين اقتصر التشريع القطري على باتى الاشتر اك النسبي، عند تعريف المصنف المشترك، على الرغم من تمييزه بين النوعين في الأحكام.

2 - إن ما يميز العمل المشترك عن العمل الجماعي، هو وجود نية الاشتراك بين المؤلفين في العمل المشترك، فكلا منهم إر ادته متجه إلى إعداد عمل تعاوني أو الاشتر اك في المصنف، ووجود شخص موجه في المصنف الجماعي يتكفل بنشر المصنف باسمه وتحت إدارته. ويحدد الهدف العام من المصنف.

3 - إن المصنف المشترك لا يكون محمياً في نظر القانون إلا إذا تو افرت فيه ذات الثروط الواجب نوافر ها لحماية المصنفات الفردية، وهي شرطان، الأول: ويتمثل في شرط الابتكار أو الإبداع الذي يقدمه المؤلف، و الثاني: يتمثل في التعبير عن المصنف، و إخر اجه إلى حيز الوجود المحسوس. 4 - إن التشريعات الخليجية قد جعلت نصيب كل مؤلف مشترك في ملكية المصنف مساويا لنصيب بقية الثركاء. ولم تجز لأي منهم أن ينفرد بمباشرة الحقوق المنرتبة عليه إذا كان المصنف مما لا يمكن فصل عمل كل شريك فيه عن عمل الآخر (الاشتر الك المطلق)، ما لم يكن هناك اتفاق على خلاف تلاك الأحكام، ونرى ضرورة أن يكون هذا الاتفاق كتابة، لتوفير أفضل حماية لحقوق المؤلفين، وهو ما نص عليه القانون البحريني و الإمار اتي والقطري و الكويتي ونظام حقوق المؤلف السعودي، ولم

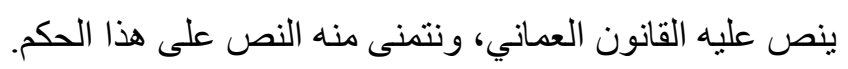

5 - إن التشريعات الخليجية قد أجازت لكل شريك الانفر اد في استغلال الجزء الذي ساهم به، ما دام هذا الجزء لا لا يندمج مع غيره (الاشتر اك النسبي)، وذلك دون طلب إذن من المؤلف المشارك الآخر. بشرط عدم الإضر ار بالمصنف المشترك بـك كما لو ساهم المشترك بنصييه في مؤلف مشابه. وقد ورد هذا الحكم في كافة النتريعات محل المقارنة، إلا أن هذه النتريعات قد أجازت الاتفاق على خلافه. و انقسمت هذه التشريعات فيما يتعلق باشتراط الكتابة من عدمه إلى قسمين، حيث الزم التشريع

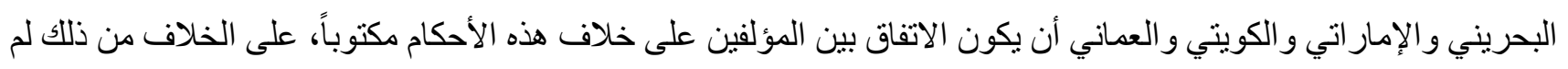
يشترط المشرع السعودي و القطري الكتابة في هذه الحالة، ونرى ضرورة أن يكون أي اتفاق يخالف الأحكام المتعلقة بالمصنف المنترك مكتوبا لحسم النزاع بين المؤلفين. 6 - إن التشريعات الخليجية اتفقت فيما بينها - عدا التشريع البحريني - فيما يتعلق بمدة حماية حقوق المؤلف في المصنفات المشتركة، حيث جعلتها خمسين سنة بعد وفاة آخر مؤلف، مع اختلاف بدايتها، من تشريع لآخر ، ونرى أن تبدأ الحماية اعتبار ا من أول السنة التالية لوفاة آخر المؤلفين، لتسهيل حساب المدة، هذا من ناحية، 
ومن ناحية أخرى جعل المشرع البحريني مدة حماية حقوق المؤلفين في المصنف المشترك سبعين سنة بعد وفاة آخر مؤلف، وفي هذا الاقتر اح، نرى أن تكون المدة خمسين سنة فقط، بعدها يكون المصنف في الملك العام، على اعتبار أن هذه المدة كافية لاستفادة الورثة، وتوحيدا للنشريع في دول مجلس التعاون الخليجي فيما يتعلق بحقوق المؤلف.

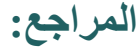

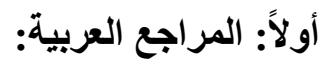

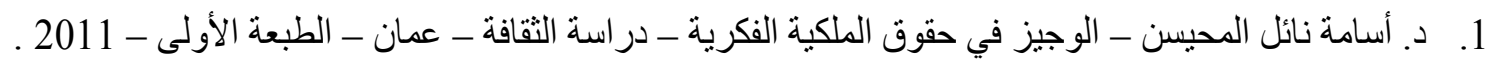
2. د. بلال عبد الله - حق المؤلف في القو انين العربية ـ المركز العربي للبحوث القانونية و القضائبة ـ جامعة الدول

$$
\text { العربية - بيروت - طبعة } 2018 .
$$

3. بوشامة هاجر، عقون بشري ـ الحماية القانونية للمصنف الجماعي - رسالة ماجستير ـ كلية الحقوق و العلوم السياسية ـ

$$
\text { جامعة } 8 \text { ماي } 1945 \text { - سنة } 2016 .
$$

4. د. حسام الأهواني - حماية حقوق الملكية الفكرية في مجال الإنترنت - بحث منشور بموقع الدليل الاككتروني للقانون العربي - www.arablawinfo.com-

5. د. حسام لطفي ـ المرجع العلمي في الملكية الأدبية و الفنية في ضوء آر اء الفقه وأحكام القضاء - طبعة 1999. 6. د. حمدي أحمد سعد - الحماية القانونية للمصنفات في النشر الإلكتروني الحديث ـ دار الكتب القانونية ـ المحلة

$$
\text { الكبرى - طبعة } 2007
$$

7. د. حلو أبو حلو، ود. سائد المحتسب- بحث بعنوان " مقدمة في الملكية الفكرية والحماية القانونية لبراءات الاختراع " -WWw.arablawinfo.com - منشور بموقع الدليل الالكتروني للقانون العربي 8. د. رقية عو اشرية ـ الحماية القانونية لحق المترجم و المصنفات المنرجمة في الوطن العربي و التحديات الر اهنة ـ مجلة علوم انسانية WWW.ULUM.NL السنة السابعة: العدد 43: خريف 2009. 9. د. سعيد عبد السلام - الحماية القانونية لحق المؤلف والحقوق المجاورة في ظل قانون حماية حقوق الملكية الفكرية رقم 82 لسنة 2002 - دار النهضة العربية - طبعة 2004.

10. د. شحاته غريب شلقامى - الملكية الفكرية في القو انين العربية ـ دار الجامعة الجديدة - طبعة 2009 ـ

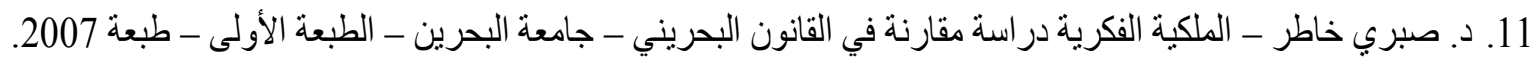
12. صلاح عبد الغني محمد ـ موسو عة المر أة المسلمة ـ الحقوق العامة للمر أة ـ الجزء الأول ـ الدار العربية للكتاب ـ طبعة 1998

13. د. طارق كاظم عجيل - حماية حقوق المصدم المعماري وفقاً لقانون حق المؤلف ـ در اسة مقارنة - بحث مقدم للمؤتمر الثامن عثر بشأن عقود البناء والتشييد بين القواعد القانونية التقليدية و النظم القانونية المستحدثة. 14. د. عبد الرشيد مأمون -حماية حق المؤلف في إطار المصنفات المشتركة ـ الدليل الالكتروني للقانون العربي. 
15. د. عبد الله النجار - الحق الأدبي للمؤلف في الفقه الإسلامي والقانون المقارن ـ دار المريخ للنشر ـ الرياض - طبعة

16. على الصادق - الحماية الجنائية لحقوق الملكية الفكرية - مقال منشور بمجلة معهد القضاء.

17. د. فتحي الدريني - حق الابتكار في الفقه الإسلامي المقارن - مؤسسة الرسالة ـ الطبعة الثانية - 1981. 18. دـ ـ كمال سعدي ـ الملكية الفكرية ـ الجزء الأول ـ حق الملكية الأدبية و الفنية ـ الطبعة الأولي -2004.

19. لويس هارمس - إنفاذ حقوق الملكية الفكرية ـ كتاب قضايا ـ الويبو ـ الطبعة الثالثة - 2012.

20. د. محمد النجار - حقوق المؤلف في ضوء الثورة المعلوماتية الحديثة ـ دراسة مقارنة ـ دار الجامعة الجديدة - طبعة

21. محمد فو از ـ المصنفات الأدبية والفنية ـ در اسة في التثريع الأردني و المصري ـ بحث منشور بالدليل الإلكتروني للقانون العربي - '

22. د. محمد شكري سرور ـالنظرية العامة للحق ـ دار النهضة العربية ـطبعة 1990 ـ 23. د. محمد محى الدين عوض - حقوق الملكية الفكرية وحمايتها قانوناً ـ بحث مقدم إلى أكاديمية نايف للعلوم الأمنية

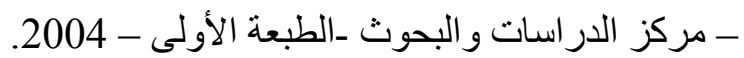

24. د. مختار القاضي - حق المؤلف ـ الكتاب الأول ـ مكتبة الأنجلو المصرية - طبعة 1958.

$$
\text { ثانياً: التشريعات: }
$$

1 - في مملكة البحرين: قانون رقم 22 لسنة 2006 بشأن حماية حقوق المؤلف والحقوق المجاورة المعدل بموجب القانون رقم

2 - في المملكة العربية السعودية: نظام حماية حقوق المؤلف الجديد 1424 هو لائحته التنفيذية الصادر بالمرسوم الملكي رقم م/ 41 بتاريخ 2 رجب 1424.

3 - في دولة الإمارات العربية المتحدة: القانون الاتحادي رقم 7 لسنة 2002 في شأن حقوق المؤلف والحقوق المجاورة. 4 - في سلطنة عمان: مرسوم سلطاني رقم 65 / 2008 بإصدار قانون حماية حقوق المؤلف و الحقوق المجاورة. 5 - في دولة الكويت: قانون رقم 75 لسنة 2019 في شأن حقوق المؤلف والحقوق المجاورة. 6 - في دولة قطر : قانون رقم (7) لسنة 2002 بشأن حماية حق المؤلف و الحقوق المجاورة.

1. Catherine Colston, LLB, LLM- Principles of Intellectual Property Law-Cavendish Publishing Limited -First published in Great Britain 1999.

2. Caroline G. Ouellet, Oeuvre créée ou non créée en collaboration? Là est la question, LEGER ROBIC RICHARD/ROBIC, 2004.

3. Chapitre préliminaire Présentation de la propriété littéraire et artistique -https://www.editionsellipses.fr/PDF/9782340015739_extrait.pdf 


$$
\text { المجلة الدولية لنشر البحوث والدراسات }
$$

International Journal of Research and Studies Publishing
المجلد الثاني - الإصدار التاسع عشر تأريخ الإصدار: 20 مايو 2021م

4. CNIPA and WIPO, Intellectual Property Basics: A Q\&A for Students China National Intellectual Property Administration (CNIPA), Switzerland, 2019.

5. Claudia Gestin-Vilion, La protection par le droit d'auteur des creations générées par intelligence artificielle, Université Laval Québec, Canada Maître en droit (LL.M.) et Université Paris-Saclay Sceaux, France, 2017.

6. Deborah E. Bouchoux -ntellectual Property - The Law of Trademarks, Copyrights, Patents ‘and Trade Secrets - Fourth Edition-Printed in the United States of America.

7. Distinction œuvre de collaboration/ œuvre collective recherche.unicaen.fr/.../com.univ.collaboratif.utils.LectureFichierg.

8. L.T.C. Harms, A Casebook on the Enforcement of Intellectual Property Rights, $4^{\text {th }}$ Edition, Switzerland, WIPO, 2018.

9. Patrick Ager, AUTHORSHIP AND JOINT, AUTHORSHIP OF MUSICAL WORKS: A QUEST FOR COMMON STANDARDS IN EU COPYRIGHT LAW, King's College London, 2013.

10. Suhail HADDADIN, ESSAI SUR UNE THEORIE GENERALE EN DROIT D’AUTEUR, Thèse pour le doctorat en droit présentée et soutenue publiquement le 22 novembre 2008 , UNIVERSITE DE POITIERS, FACULTE DE DROIT ET DES SCIENCES SOCIALES.

11. Thomas Margoni \& Mark Perry - OWNERSHIP IN COMPLEX AUTHORSHIP: A COMPARATIVE STUDY OF JOINT WORKS IN COPYRIGHT LAW-2011 https://papers.ssrn.com/sol3/papers.cfm?abstract_id=1992610

Doi: $\underline{\text { doi.org/10.52133/ijrsp.v2.19.1 }}$ 